\title{
Ascorbic Acid, Alcohol, and Environmental Chemicals ${ }^{a}$
}

\author{
V. G. ZANNONI, J. I. BRODFUEHRER, R. C. SMART, ${ }^{b}$ \\ AND R. L. SUSICK, JR. ${ }^{c}$ \\ Department of Pharmacology \\ University of Michigan Medical School \\ Ann Arbor, Michigan 48109
}

\section{INTRODUCTION}

It is apparent through the efforts of a number of investigators that ascorbic acid is involved in the metabolism and detoxification of numerous xenobiotics. Interestingly, the vitamin participates at a variety of levels, including the important hepatic electron transport systems, i.e., cytochrome P-450 mixed function oxygenase (MFO) $)^{1-21}$ and flavin-containing monooxygenase (FMO) $)^{22-24}$; protection against covalent binding of "reactive intermediates" to macromolecular protein $\mathrm{s}^{25-49}$; and more recently involvement in the metabolism and toxicological consequences of a most commonly used and abused drug, alcohol. ${ }^{51-61,63,66}$ Although the precise biochemical mechanism of the vitamin's participation at these levels warrants further investigation, the role of ascorbic acid in xenobiotic metabolism may have important consequences.

\section{RESULTS}

\section{Ascorbic Acid and Hepatic Electron Transport Systems}

It has been previously established and well documented that the hepatic microsomal cytochrome P-450 mixed function oxygenase (MFO) electron transport system is markedly reduced in vitamin $C$ deficiency. ${ }^{3,7,15,20}$ In addition, more recently, it has been demonstrated that the flavin-monooxygenase transport system (FMO), ${ }^{22-24}$ responsible for the metabolism of many nitrogen- and sulfur-containing xenobiotics, is also jeopardized in vitamin $\mathrm{C}$ deficiency (TABLE 1). Guinea pigs maintained on an

\footnotetext{
${ }^{a}$ This work supported in part by grant no. 23007 from Hoffmann-La Roche, Inc., Nutley, N.J. and grant nos. 5M01-RR00042 and 2 P60 AM20572 from the National Institutes of Health.

${ }^{b}$ Present address: Toxicology Program, North Carolina State University, Raleigh, N.C. 27695.

${ }^{c}$ Present address: Department of Pathology and Experimental Toxicology, Warner-Lambert/ Parke-Davis, Ann Arbor, Mich. 48105.
} 


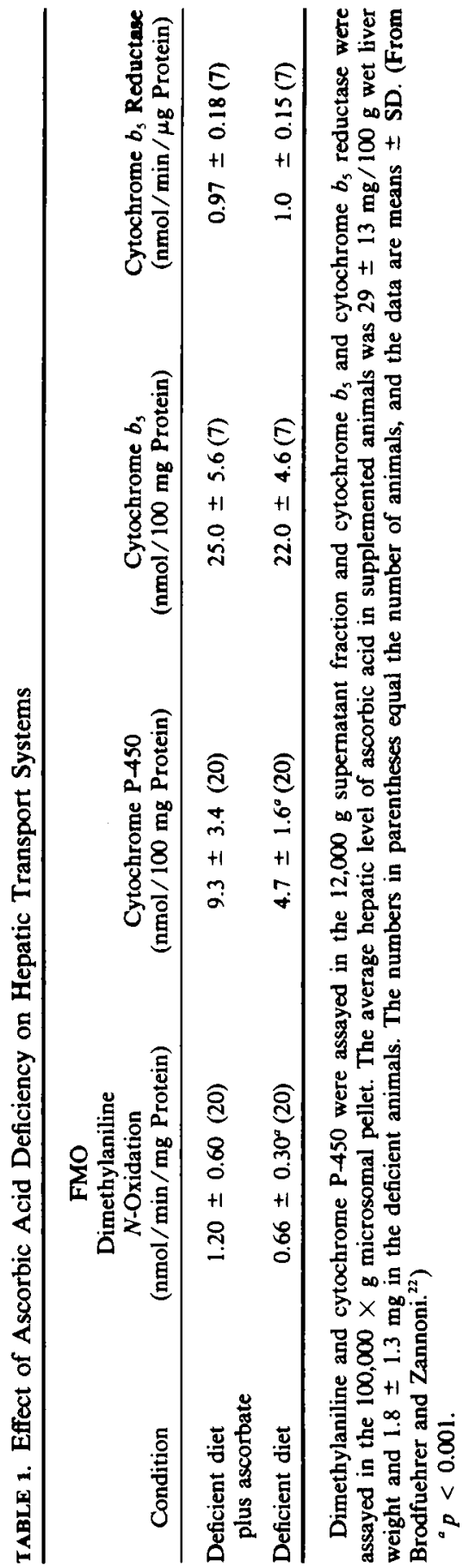


ascorbic-acid-free diet had a significant reduction $(45 \%)$ in the $N$-oxidation of dimethylaniline, a substrate for the FMO. Cytochrome P-450 was also reduced, whereas the microsomal heme-containing cytochrome $b_{5}$ and the flavin-containing $b_{5}$ reductase were not affected. The decrease in FMO could be differentiated from the decrease in the MFO system by the use of specific inhibitors, phenobarbital pretreatment, thermal treatment, and $\mathrm{pH}$ activity profiles. The effect of inhibitors is shown in FiguRES 1A and $1 \mathrm{~B}$. The $\mathrm{N}$-oxidation of dimethylaniline (DMA), a FMO substrate, was in fact stimulated (twofold) by $3 \mathrm{mM} n$-octylamine (FIG. 1A), while aniline, an MFO substrate, was inhibited $90 \%$. Also, SKF-525A, another MFO inhibitor, caused a decrease of $60 \%$ in the metabolism of $p-\mathrm{NO}_{2}$ anisole, an MFO substrate, and did not affect the $N$-oxidation of DMA (FIG. 1B). Phenobarbital pretreatment of guinea pigs did not induce FMO, while the MFO was induced twofold in both ascorbic-acidsupplemented and ascorbic-acid-deficient guinea pigs. The FMO could be selectively inactivated at $50^{\circ} \mathrm{C}(95 \%)$, while the $\mathrm{MFO}$ was not significantly altered. In addition, FMO activity was reduced by $50 \%$ at $\mathrm{pH} 7.0$ in preparations from both ascorbatesupplemented and ascorbic-acid deficient animals while no significant decrease of MFO activity was observed at this $\mathrm{pH}$. In addition to the decrease in FMO due to the deficiency of the vitamin, there was a further decrease in FMO activity in the deficient guinea pigs who had lost up to $10-15 \%$ of their body weight compared to ascorbicacid-supplemented animals (TABLE 2). Guinea pigs on an ascorbic-acid deficient diet that had no significant weight loss had a $40 \%$ reduction in FMO activity, while the ascorbic acid deficient animals that had lost $10-15 \%$ of their body weight had a reduction of $83 \%$.

Purification of the FMO from ascorbic-acid-deficient and ascorbic-acid-supplemented guinea pig livers with DEAE cellulose and Blue-2-Agarose column chromatography resulted in two FMO fractions ( $A$ and $B$ ) in both cases. Fraction $A$ was eluted with $0.35 \mathrm{M} \mathrm{KCl}, \mathrm{pH} 7.8$, and required exogenous FAD $(0.05 \mathrm{mM})$ for optimal activity. The recovery of enzyme activity in the fraction from ascorbic-acid-deficient microsomal preparations was four times greater than microsomal preparations from ascorbic-acid supplemented guinea pigs. There was, however, a marked reduction in the quantity of FMO activity in the B fraction isolated from the ascorbic-acid-deficient microsomes: a $5 \%$ recovery compared to a $25 \%$ recovery for the ascorbic-acidsupplemented animals. Furthermore, subjection of purified preparations (30- to 120 fold; DEAE, Blue-2-Agarose, and 2', 5'-ADP Sepharose) to polyacrylamide gel electrophoresis resulted in a marked decrease in the quantity of protein banding at 56,000 daltons in enzyme prepared from vitamin-C-deficient animals. ${ }^{24}$

Purified FMO isolated from ascorbic-acid-deficient animals was unstable to freezing at $-20^{\circ}$, whereas comparable preparations from ascorbic-acid-supplemented animals maintained over $90 \%$ of their activity up to 4 weeks. Furthermore, marked substrate inhibition occurred with enzyme prepared from the ascorbic-acid-deficient animals. At $2 \mathrm{mM}$ DMA, the initial rate of the reaction as measured for 100 seconds was linear with time and comparable to enzyme purified from the ascorbic-acid-supplemented animals. However, this initial rate decreased at 400 seconds, a more than 95\% decrease with enzyme prepared from ascorbic-acid-deficient animals compared to a decrease of $40 \%$ with enzyme prepared from ascorbic-acid-supplemented animals. ${ }^{24}$

Kinetic experiments with purified preparations from ascorbic-acid-deficient or supplemented animals indicated no significant difference in the affinity of either DMA or NADPH. The $K_{m}$ for DMA is $3.1 \times 10^{-4} \mathrm{M}$ for enzyme prepared from ascorbicacid-deficient animals and $3.2 \times 10^{-4} \mathrm{M}$ for enzyme prepared from ascorbic-acidsupplemented animals. The $K_{m}$ for NADPH is $7.7 \times 10^{-5} \mathrm{M}$ for ascorbic-aciddeficient and $3.8 \times 10^{-5} \mathrm{M}$ for ascorbic-acid-supplemented animals for FMO activity associated with the $B$ fraction. The apparent affinity for FAD with purified FMO fraction $\mathrm{A}$ isolated from ascorbic-acid-deficient animals was $8.0 \times 10^{-7} \mathrm{M}^{24}$ 

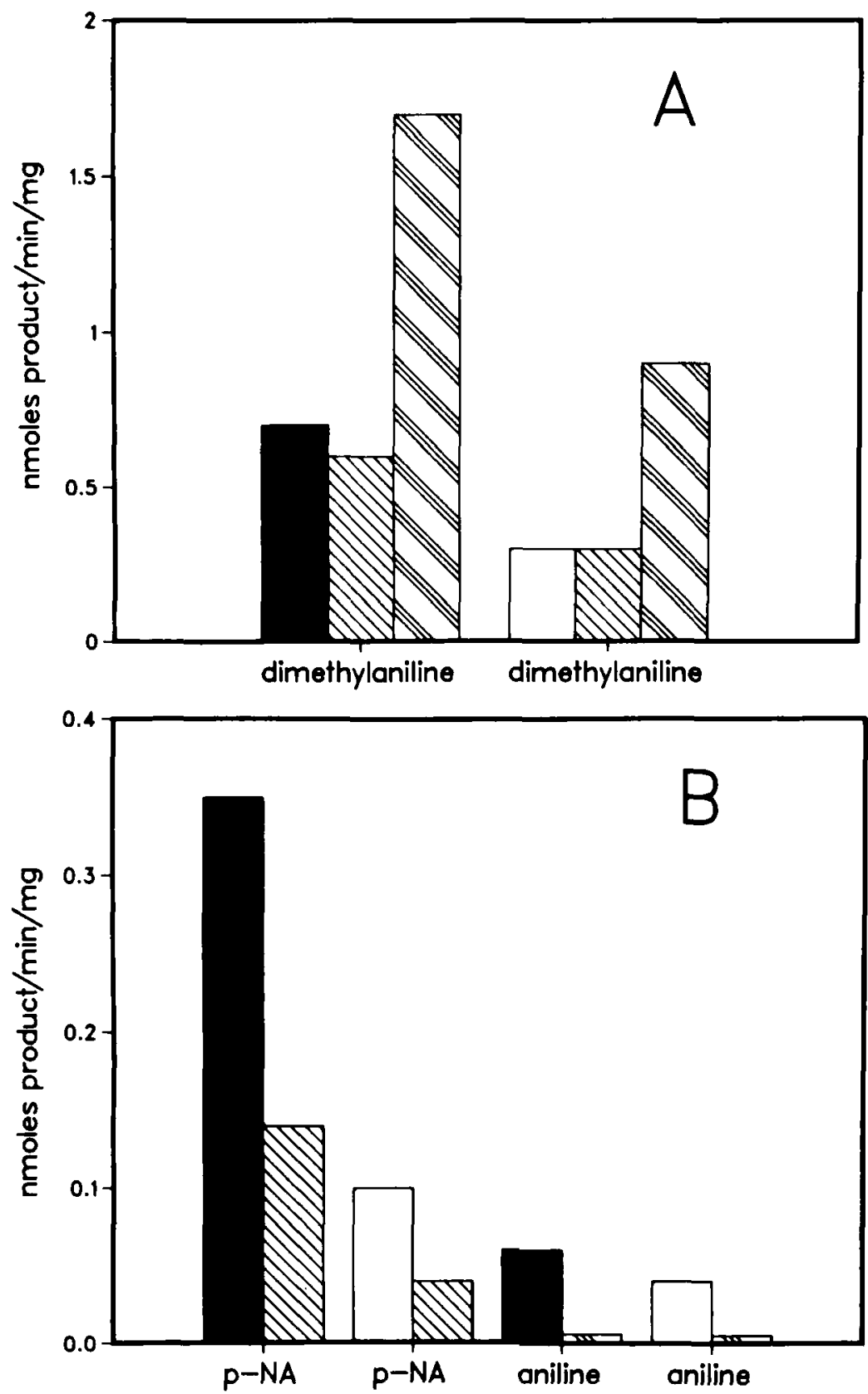

FIGURE 1. (A,B) Effect of cytochrome P-450 inhibitors. Activity is measured as nmoles product per min per mg 12,000 $\times \mathrm{g}$ hepatic supernatant fraction. For DMA the $N$-oxide product was determined. $\mathrm{p}-\mathrm{Na}$, p-nitroanisole. The average hepatic level of ascorbic acid in supplemented animals was $29 \pm 13 \mathrm{mg} / 100 \mathrm{~g}$ wet liver and $1.8 \pm 1.3$ in the deficient animals. The data presented in the figure represent a typical experiment: $\square=$ plus ascorbate diet; $\square=$ no ascorbate diet; $\mathbb{N}=\mathrm{SKF}-525 \mathrm{~A}, 1 \mathrm{mM}$; and $\mathbf{S}=n$-octylamine, $3 \mathrm{mM}$. (From Brodfuehrer and Zannoni. ${ }^{22}$ Reprinted by permission of Biochemical Pharmacology.) 
TABLE 2. Effect of Ascorbic Acid on Hepatic Flavin Monooxygenase ${ }^{a}$

\begin{tabular}{lcc}
\hline \multicolumn{1}{c}{ Diet } & $\begin{array}{c}\text { FMO } \\
(\mathrm{nmol} / \mathrm{min} / \mathrm{mg} \text { Protein })\end{array}$ & $\begin{array}{c}\text { Liver Ascorbate } \\
(\mathrm{mg} / \mathrm{g} \text { Wet Liver wt) }\end{array}$ \\
\hline $\begin{array}{l}\text { 10-15\% Weight Loss } \\
\text { Deficient diet plus ascorbate }\end{array}$ & $2.3 \pm 0.5(6)$ & $20.9 \pm 4.5(6)$ \\
Deficient diet, no ascorbate & $0.4 \pm 0.08^{b}(5)$ & $1.9 \pm 1.4(5)$ \\
No Weight Loss & & \\
Deficient diet plus ascorbate & $1.3 \pm 0.4^{d}(7)$ & $22.0 \pm 6.6(7)$ \\
Deficient diet, no ascorbate & $0.8 \pm 0.3^{\text {ce. }}(7)$ & $1.3 \pm 0.5(7)$ \\
\hline
\end{tabular}

${ }^{a}$ Dimethylaniline $N$-oxidation was assayed in the $12,000 \mathrm{~g}$ hepatic supernatant fraction. The numbers in parentheses are the number of animals and the data are means \pm SD.

${ }^{b}$ The mean value is significantly different $(p<0.001)$ compared to the corresponding plus ascorbate group.

'The mean value is significantly different $(p<0.02)$ compared to the corresponding plus ascorbate group.

"The mean value is significantly different $(p<0.01)$ compared to the corresponding group that lost weight.

"The mean value is significantly different $(p<0.02)$ compared to the corresponding group that lost weight.

(Modified from Brodfuehrer and Zannoni. ${ }^{23}$ )

\section{Ascorbic Acid and Covalent Binding}

Several laboratories have demonstrated a protective effect of ascorbic acid against covalent binding of reactive xenobiotic intermediates to macromolecular protein. ${ }^{25-36}$ Benzene and its metabolites exemplify this protective property of the vitamin. Upon chronic exposure, benzene produces hemopoietic toxicity resulting in reported cases of aplastic anemia. ${ }^{37,38}$ It has also been implicated as a human leukemogen. ${ }^{39}$ The toxicological consequences are thought to be via metabolic activation of benzene presumably through covalent binding of its metabolites to protein. ${ }^{40-49} \mathrm{~A}$ possible metabolic pathway of benzene or its metabolite, phenol, leading to intermediates capable of covalent binding to protein is given in FIGURE 2. Benzene is oxidized to phenol, via the P-450 system, and phenol is further metabolized to catechol or hydroquinone. Subsequent oxidation of phenol through $1 e^{-}$steps lead to semiquinone intermediates and quinoid products. Peroxidases can catalize the oxidative steps; diaphorases are capable of reducing the quinoid products to hydroquinone and catechol.

The ability of ascorbic acid to inhibit covalent binding of benzene or phenol metabolites is shown in TABLE 3. The inhibition by ascorbic acid was $75 \%$ with benzene. Glutathione caused marked inhibition of binding (95\%). When phenol was incubated with hepatic microsomes, ascorbic acid or glutathione inhibited over $95 \%$. Ascorbic acid can reduce quinoids while GSH can form adducts with them. The effect of ascorbic acid on covalent binding when phenol was incubated with horseradish peroxidase or myeloperoxidase isolated from guinea pig marrow is shown in TABLE 4. HRP increased the covalent binding of phenol metabolites 30 -fold and myeloperoxidase increased it sixfold compared to the binding that occurred in their absence (TABles 3 and 4 ). The binding was decreased over $95 \%$ by $1 \mathrm{mM}$ ascorbic acid (TABLE 4). 
The effect of DT diaphorase, ascorbic acid, or glutathione on the covalent binding of benzene or phenol metabolites is shown in FIGURES 3A and 3B. With benzene as the substrate, DT-diaphorase inhibited binding by only $18 \%$, ascorbic acid inhibited it by $55 \%$ and GSH by $95 \%$ (FIG. 3A). In contrast, with phenol as the substrate, DT-diaphorase inhibited binding by $70 \%$ and ascorbic acid or GSH inhibited binding over 95\% (FIG. 3B). Ascorbic acid or GSH had no significant effect on MFO metabolism of phenol or hydroquinone. However, ascorbic acid decreased the formation of phenol from benzene by $35 \% .^{33}$

The effect of dietary ascorbic acid on the covalent binding of phenol metabolites with bone marrow, the target tissue for the toxicological events, was also determined. Covalent binding in bone marrow homogenates isolated from guinea pigs on an ascorbic-acid-free diet was fourfold higher than the bone marrow isolated from animals receiving $0.5 \mathrm{mg}$ ascorbic acid per $\mathrm{ml}$ of drinking water (TABLE 5). In addition, the bone marrow ascorbic acid concentration was tenfold higher in the ascorbic-acidtreated animals while the GSH concentration in the bone marrow was not significantly different between the two groups. In view of these results, the effect of ascorbic acid

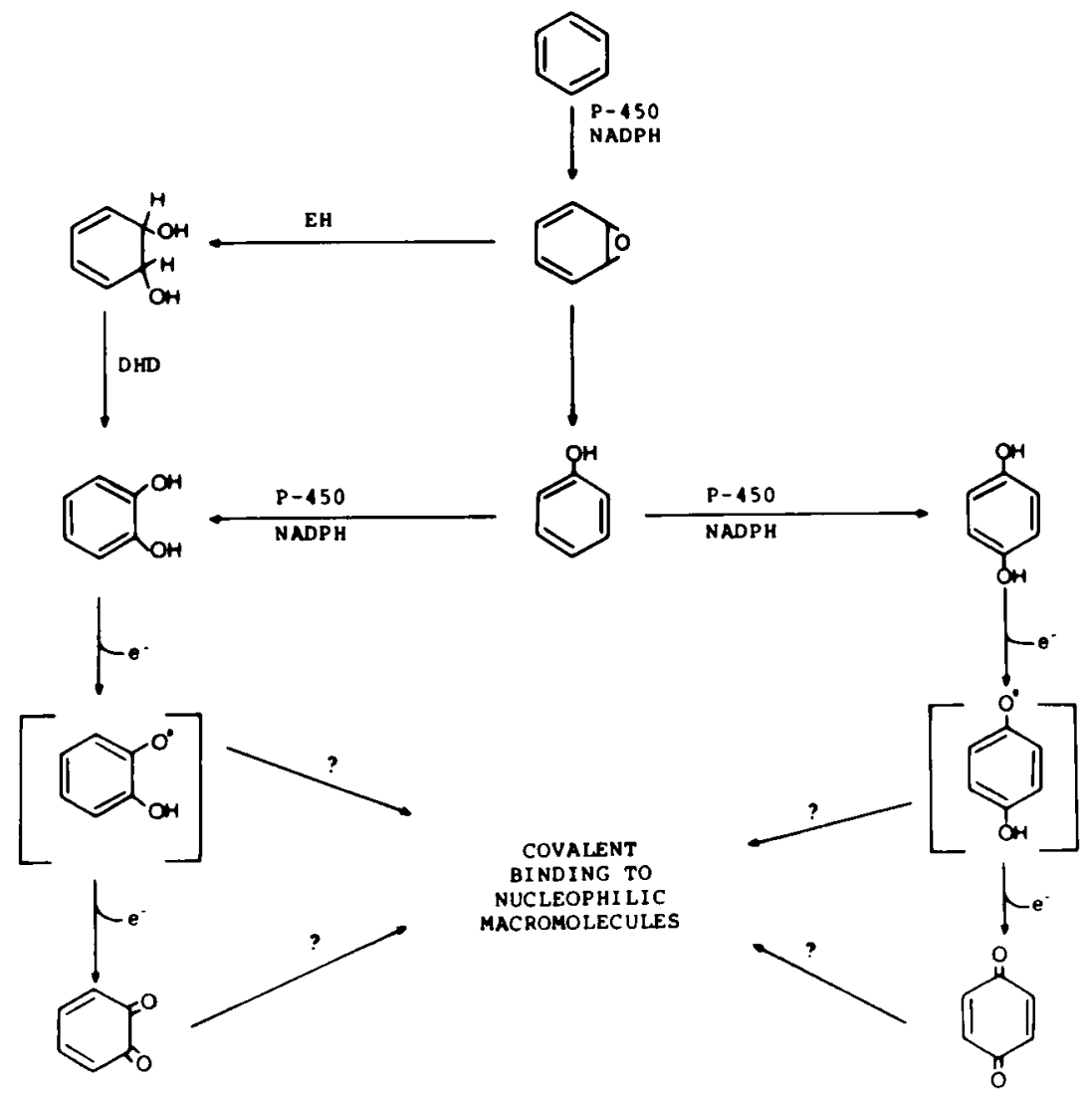

FIGURE 2. Proposed metabolic pathway of benzene or phenol leading to intermediates capable of covalent binding. (From Smart and Zannoni. ${ }^{34}$ Reprinted by permission of Molecular Pharmacology.) 
TABLE 3. Effect of Ascorbic Acid and Glutathione on Covalent Binding of $\left[{ }^{14} \mathrm{C}\right]$ Benzene Metabolites to Hepatic Microsomal Protein in Vitro

\begin{tabular}{|c|c|}
\hline Additions & $\begin{array}{c}\text { Covalent Binding }^{a} \\
\text { (pmol Phenol or } \\
\text { Benzene Equivalents } \\
\text { Bound } / \mathrm{min} / \text { mg Microsomal Protein) }\end{array}$ \\
\hline \multicolumn{2}{|l|}{ With $\left[{ }^{14} \mathrm{C}\right]$ Benzene } \\
\hline None (control with NADPH) & $104.4 \pm 18.8(3)^{b}$ \\
\hline Ascorbate $(1 \mathrm{mM})$ & $29.9 \pm 3.4(3)$ \\
\hline Glutathione (1 mM) & $3.3 \pm 2.2(3)$ \\
\hline \multicolumn{2}{|l|}{ With $\left[{ }^{14} \mathrm{C}\right]$ Phenol } \\
\hline None (control with NADPH) & $252.7 \pm 12.3(4)$ \\
\hline Ascorbate $(1 \mathrm{mM})$ & $13.4 \pm 1.7(4)$ \\
\hline Glutathione (1 mM) & $1.0 \pm 1.9(4)$ \\
\hline
\end{tabular}

$\left[{ }^{14} \mathrm{C}\right]$ Phenol $(1 \mathrm{mM})$ or $\left[{ }^{14} \mathrm{C}\right]$ benzene $(1 \mathrm{mM})$ were incubated with $0.7-1.0 \mathrm{mg}$ of washed hepatic microsomal protein isolated from phenobarbital-pretreated guinea pigs, NADPH (1 mM), and sodium phosphate buffer $(100 \mathrm{mM}, \mathrm{pH} 7.4)$. The incubation was carried out for 10 or $15 \mathrm{~min}$ at $37^{\circ} \mathrm{C}$. The total volume was $1 \mathrm{ml}$. (Modified from Smart and Zannoni. ${ }^{35}$ )

${ }^{\circ}$ Values are expressed as $\bar{x} \pm \mathrm{SD}$.

"The number in parentheses equals the number of experiments done in duplicate.

on covalent binding of benzene metabolites after i.p. administration of $\left[{ }^{14} \mathrm{C}\right]$ benzene to guinea pigs placed on different dietary intakes of the vitamin was determined. In both liver and bone marrow, the binding decreased with higher tissue concentrations of ascorbic acid. In the liver the decrease was $50 \%$ with animals with $2.63 \mu \mathrm{mol}$ ascorbate per $\mathrm{g}$ liver compared to animals with $0.28 \mu \mathrm{mol}$ ascorbic acid per $\mathrm{g}$ (FIG. 4). In the marrow the decrease was on the order of $30 \%$ with animals with 1.84 $\mu \mathrm{mol}$ ascorbic acid per $\mathrm{g}$ marrow compared to animals with $0.12 \mu \mathrm{mol}$ ascorbic acid per g marrow (FIG. 5).

\section{Ascorbic Acid and Alcohol}

The involvement of ascorbic acid in alcohol metabolism and toxicity is of current interest and has been studied in several laboratories. ${ }^{31-63,66}$ The principal enzymatic pathways for the oxidation of methanol or ethanol to their aldehydes include cytosolic alcohol dehydrogenase, which utilizes $\mathrm{NAD}^{+}$; cytosolic alcohol dehydrogenase, which utilizes $\mathrm{H}_{2} \mathrm{O}_{2}$; and the cytochrome $\mathrm{P}-450$ mixed function oxygenase system (MFO), which requires $\mathrm{NADPH}$ and $\mathrm{O}_{2}$. In vitro studies in our laboratory indicate that ascorbic acid can promote alcohol oxidation via a catalase-mediated reaction. ${ }^{37} \mathrm{~A}$ comparison of this ascorbate-dependent alcohol oxidizing system to the alcohol dehydrogenase and the cytochrome P-450 microsomal system is shown in TABLE 6. The ascorbatedependent system was over 200 times more active than the microsomal system for both methanol and ethanol; it was over $\mathbf{5 0 0}$ times more active for methanol and over 100 times more active for ethanol compared to alcohol dehydrogenase. The effect of catalase inhibitors on the ascorbate-dependent alcohol oxidation is given in TABLE 7. Sodium azide and 3-amino-1,2,4-triazole were effective inhibitors with hepatic super- 
natant, $12,000 \times \mathrm{g}$ hepatic pellet fractions, and when purified catalase was used as the enzyme source. When a peroxide generating system was used in place of ascorbic acid, the amount of inhibition with azide or triazole was comparable to the ascorbatedependent system. A comparison of oxygen consumption, $\mathrm{H}_{2} \mathrm{O}_{2}$ production, and alcohol oxidation utilizing ascorbic acid or a $\mathrm{H}_{2} \mathrm{O}_{2}$ generating system is further evidence for an ascorbic-acid-catalase mediated reaction (TABLE 8). Hydrogen peroxide was produced and $\mathrm{O}_{2}$ consumed with either ascorbic acid or a $\mathrm{H}_{2} \mathrm{O}_{2}$ generating system. However, more oxygen was consumed with the ascorbic acid system than could be accounted for by its incorporation into $\mathrm{H}_{2} \mathrm{O}_{2}$. The active oxidizing species of catalase and $\mathrm{H}_{2} \mathrm{O}_{2}$ is catalase- $\mathrm{H}_{2} \mathrm{O}_{2}$ complex I, which can be measured spectrophotometrically. ${ }^{50} \mathrm{~A}$ comparison of alcohol oxidation and complex I formation utilizing either an $\mathrm{H}_{2} \mathrm{O}_{2}$ generating system or ascorbic acid resulted in the formation of complex I. Furthermore, upon addition of alcohol the quantity of complex I was reduced in both cases."

In view of the in vitro participation of ascorbic acid in alcohol metabolism, a determination of any in vivo protective effect of the vitamin against the toxicity of ethanol was of interest. The vitamin has been previously assessed, but to a limited degree, and in the main, in species that can synthesize it. ${ }^{51,55,36}$ Yunice and coworkers did, however, find protection against hepatic steatosis by ascorbic acid in guinea pigs, a species which cannot synthesize the vitamin. In this study the animals were chronically infused with ethanol. ${ }^{61}$ The data presented in TABLE 9 are the result of an acute study in our laboratory in which serum enzymes, triglycerides, and liver weight to body weight ratios were determined after a single dose of ethanol given to guinea pigs on various regimens of ascorbic acid. Animals with hepatic ascorbic acid concentrations

TABLE 4. Effect of HRP and Myeloperoxidase on Covalent Binding of $\left[{ }^{14} \mathrm{C}\right]$ Phenol and Metabolites to Microsomal Protein in Vitro

\begin{tabular}{|c|c|}
\hline Condition & $\begin{array}{l}\text { Covalent Binding } \\
\text { (pmol Phenol } \\
\text { Equivalents } \\
\text { Bound } / \text { min } / 0.7 \mathrm{mg} \\
\text { Microsomal Protein) }\end{array}$ \\
\hline $\mathrm{HRP}^{t}(0.12$ unit $), \mathrm{H}_{2} \mathrm{O}_{2}(8.8 \mathrm{mM})$ & $8287.8 \pm 995.5$ \\
\hline $\begin{array}{l}\text { HRP }\left(0.12 \text { unit), } \mathrm{H}_{2} \mathrm{O}_{2}(8.8 \mathrm{mM})\right. \\
\text { ascorbate }(1 \mathrm{mM})\end{array}$ & $50.8 \pm 23.3^{e}$ \\
\hline $\begin{array}{l}\text { Myeloperoxidase }^{b}(0.17 \text { unit }) \\
\qquad \mathrm{H}_{2} \mathrm{O}_{2}(8.8 \mathrm{mM})\end{array}$ & $1458.6 \pm 57.2$ \\
\hline $\begin{array}{l}\text { Myeloperoxidase }(0.17 \text { unit }), \\
\mathrm{H}_{2} \mathrm{O}_{2}(8.8 \mathrm{mM}) \\
\text { ascorbate }(1 \mathrm{mM})\end{array}$ & $70.6 \pm 20.1^{\circ}$ \\
\hline $\mathrm{H}_{2} \mathrm{O}_{2}(4.4 \mathrm{mM})$ & $114.1 \pm 32.1^{\circ}$ \\
\hline
\end{tabular}

$\left[{ }^{14} \mathrm{C}\right]$ Phenol $(1 \mathrm{mM})$ was incubated with $0.7 \mathrm{mg}$ of washed hepatic microsomal protein isolated from PB-pretreated guinea pigs and sodium phosphate buffer (100 mM, pH 7.4). The incubation was carried out for $5 \mathrm{~min}$ at $37^{\circ} \mathrm{C}$. The total volume was $1 \mathrm{ml}$. (Modified from Smart and Zannoni. ${ }^{34}$ )

- Values are means \pm standard deviation, $n=4,1$ unit $=1 \mu \mathrm{mol}$ of guaiacol oxidized/ $\mathrm{min} / \mathrm{mg} ;$ HRP $=126$ units $/ \mathrm{mg}$; guinea pig myeloperoxidase $=1.3$ units $/ \mathrm{mg}$.

${ }^{b}$ Control.

'Significantly different from control $(p<0.01)$. 

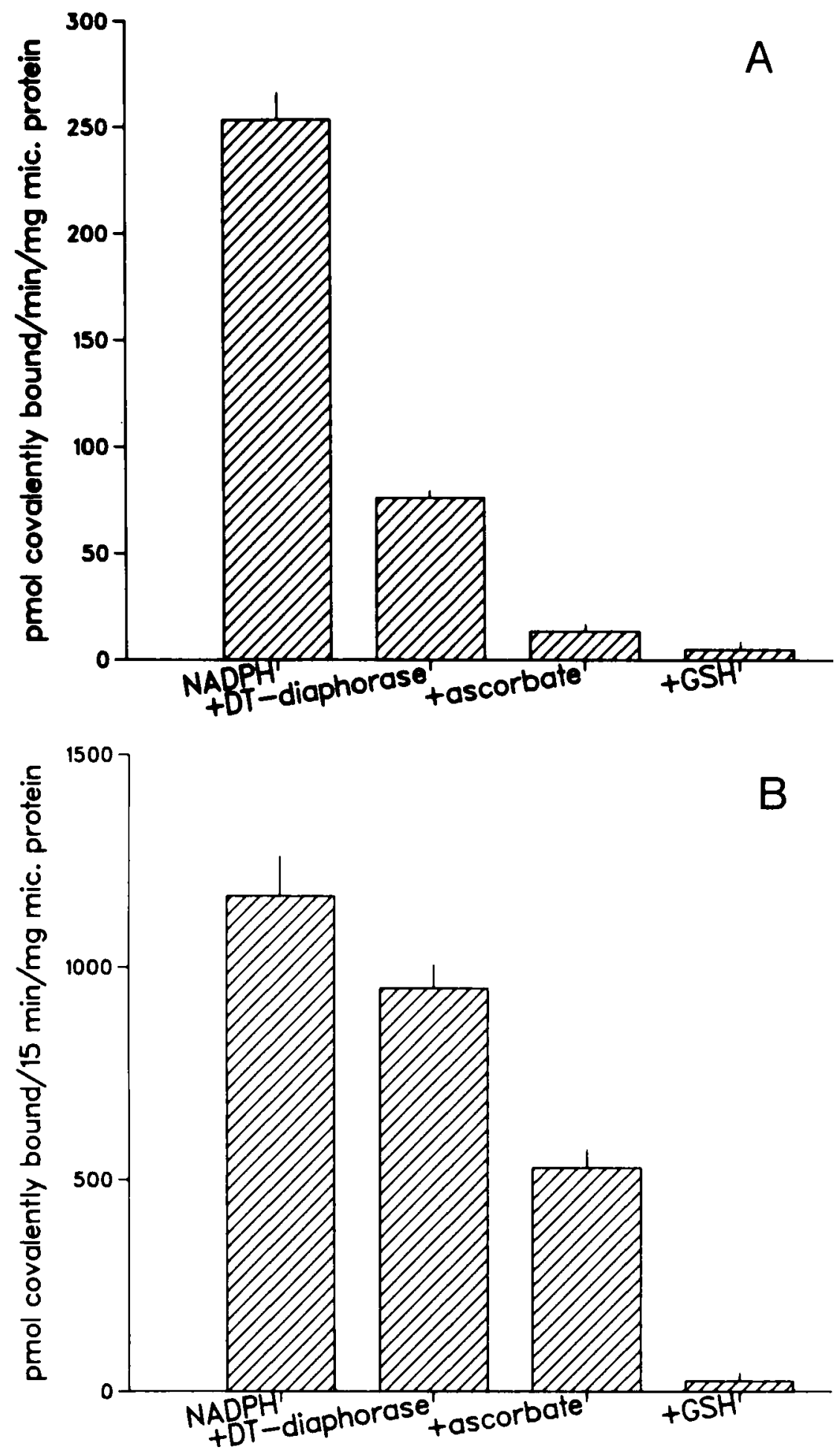
from 1 to $16 \mathrm{mg}$ per $100 \mathrm{~g}$ liver had a 12 -fold increase in SGOT levels. In contrast, animals with hepatic concentrations of the vitamin from 17 to $36 \mathrm{mg}$ per $100 \mathrm{~g}$ liver had only a fivefold increase. The significance between the SGOT levels of these groups was $p<0.01$. No correlation was found between the concentrations of the vitamin and levels of SGPT or serum triglycerides. In addition, there was no significant increase in ethanol clearance in animals with 1 to $16 \mathrm{mg}$ ascorbic acid per $100 \mathrm{~g}$ liver (773 $\pm 104 \mu \mathrm{mol}$ per $100 \mathrm{ml}$ per $\mathrm{h}$ ) compared to animals with liver ascorbic acid concentrations above $16 \mathrm{mg}$ per $100 \mathrm{~g}$ liver $(755 \pm 55 \mu \mathrm{mol}$ per $100 \mathrm{ml}$ per h).

The data in TABLE 10 are the result of a study to determine the effect of ascorbic acid on chronic alcohol consumption in the guinea pig. Levels of SGOT and SGPT were significantly elevated in animals on the low ascorbic acid diet that had received alcohol: $120 \%$ and $250 \%$. Figures $6 \mathrm{~A}$ and $6 \mathrm{~B}$ give a representative example of guinea pigs on a low or high ascorbic acid diet that received alcohol for 14 weeks. The development of hepatic steatosis is shown in the figure. Half of the animals on the low ascorbic acid diet also developed necrosis of their hepatocytes. None of the animals on the high ascorbic acid diet that received alcohol manifested these changes.

Based on the in vivo animal studies demonstrating that ascorbic acid gave some protection against alcohol toxicity, and the in vitro studies demonstrating ascorbic acid involvement in alcohol oxidation, a determination was made on the effect of the vitamin on the consequences of acute alcohol consumption in man. ${ }^{59}$ The study included ethanol clearance, toxicity, and behavioral patterns. Ascorbic acid pretreatment resulted in a significant increase in blood ethanol clearance. Ten subjects had a greater than $10 \%$ difference in clearance after vitamin pretreatment. Nine of these ten subjects had an $11-74 \%$ increase in clearance; one had a $15 \%$ decrease. Of the remaining ten subjects, four had an increase in clearance of $1-10 \%$, five had a decrease of $1-10 \%$, and one had no change. In general, those individuals who had the largest increase in clearance with ascorbic acid pretreatment were those with the slowest clearance with the placebo (FIG. 7). In addition, ascorbic acid pretreatment resulted in a significantly higher level of serum triglycerides (FIG. 8). Eleven subjects had a greater than $20 \%$ difference in serum triglyceride levels after ascorbic acid pretreatment. Ten of these eleven subjects had a 36-133\% increase in triglyceride levels; one subject had a $30 \%$ decrease. Of the remaining nine subjects, four had a $10-20 \%$ increase, four had a 1-20\% decrease, and one had no change. Ascorbic acid pretreatment did not significantly influence blood lactate : pyruvate ratios.

FIGURE 3. (A) Effect of DT-diaphorase, ascorbate, or GSH on covalent binding of benzene metabolites with microsomes isolated from benzene-pretreated guinea pigs. The incubation contained $\left[{ }^{14} \mathrm{C}\right.$ ]benzene $(1 \mathrm{mM}), 2$ units DT-diaphorase, ascorbate $(1 \mathrm{mM})$, or GSH $(1 \mathrm{mM})$. One unit of DT-diaphorase is defined as $1 \mu \mathrm{mol}$ of $p$-benzoquinone reduced $/ \mathrm{min}$. Each value represents the mean of three experiments done in duplicate \pm SD. (B) Effect of DT-diaphorase, ascorbate, or GSH on covalent binding of phenol metabolites with microsomes isolated from phenobarbital-pretreated guinea pigs. The incubation contained $\left[{ }^{14} \mathrm{C}\right]$ phenol $(1 \mathrm{mM}), 2$ units DT-diaphorase, ascorbate $(1 \mathrm{mM})$, or GSH $(1 \mathrm{mM})$. One unit of DT-diaphorase is defined as $1 \mu \mathrm{mol} p$-benzoquinone reduced/min. Each value represents the mean of three experiments done in duplicate \pm SD. (From Smart and Zannoni. ${ }^{35}$ Reprinted by permission of Toxicology and Applied Pharmacology.) 
TABLE 5. Effect of Dietary Ascorbate on Covalent Binding of $\left[{ }^{14} \mathrm{C}\right]$ Phenol with Isolated Bone Marrow Preparations from Pair-Fed Guinea Pigs ${ }^{a, b}$

\begin{tabular}{lcc}
\hline Diet & $\begin{array}{c}\text { pmol Phenol } \\
\text { Equivalents Covalently } \\
\text { Bound / } 5 \text { min }^{c}\end{array}$ & $\begin{array}{c}\text { mg\% } \\
\text { Ascorbate } \\
\text { (Hepatic) }^{c}\end{array}$ \\
\hline $\begin{array}{l}0.5 \mathrm{mg} \text { ascorbate per } \mathrm{ml} \text { drinking water; } \\
\text { ascorbate-free guinea pig chow }\end{array}$ & $882.3 \pm 105.5$ & $34.7 \pm 17.9$ \\
$\begin{array}{l}0.0 \mathrm{mg} \text { ascorbate per } \mathrm{ml} \text { drinking water; } \\
\text { ascorbate-free guinea pig chow }\end{array}$ & $3108.7 \pm 159.2$ & $3.1 \pm 1.6$ \\
\hline
\end{tabular}

${ }^{a} n=5$ individual guinea pigs per group.

${ }^{b}$ All incubations contained $\left[{ }^{14} \mathrm{C}\right]$ phenol $(1 \mathrm{mM})$, sodium phosphate buffer $(1 \mathrm{mM}, \mathrm{pH} 7.4)$, $\mathrm{H}_{2} \mathrm{O}_{2}(8.8 \mathrm{mM}), 35 \mathrm{mg}$ bone marrow tissue, and $0.7 \mathrm{mg}$ microsomal protein.

'Values are expressed as the means of five individual values \pm SD.

(From Smart and Zannoni. ${ }^{35}$ )

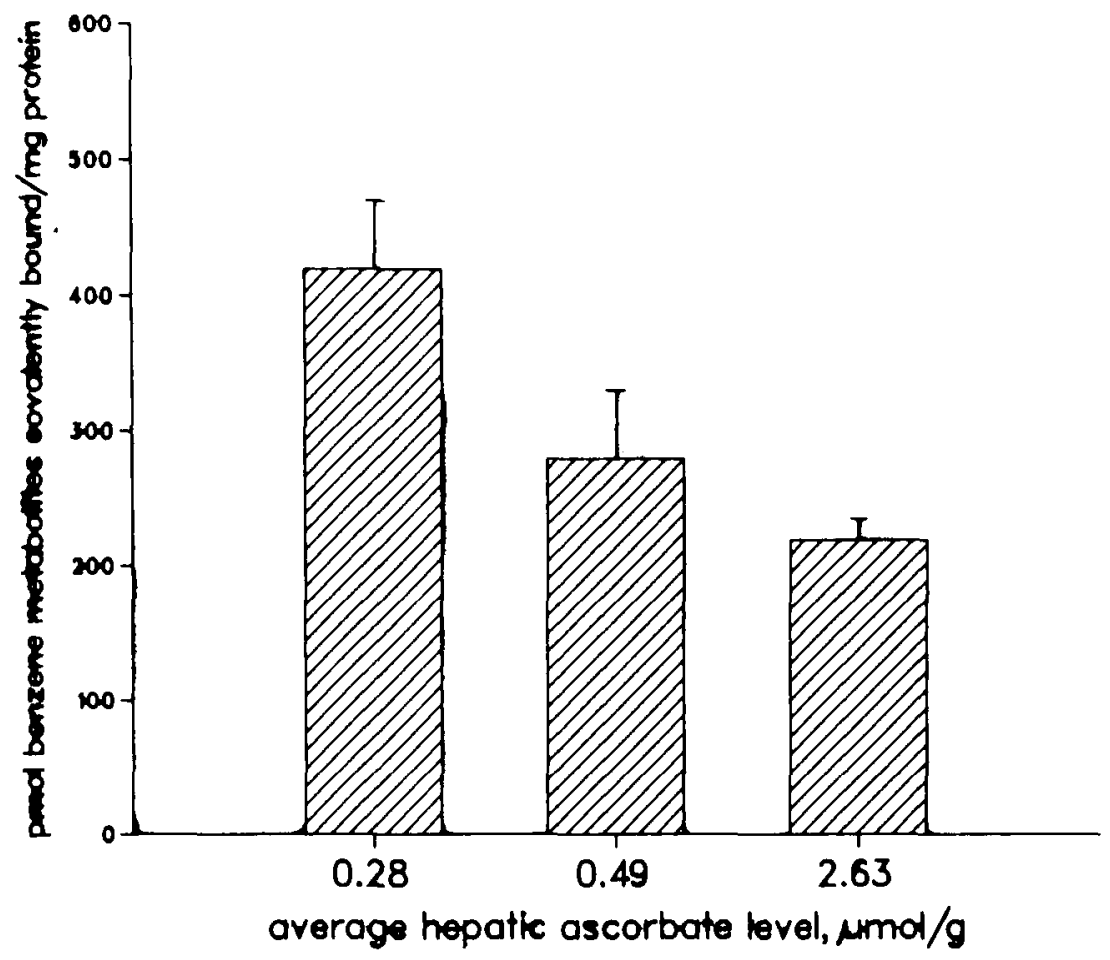

FGURT 4. Covatent binding of the metabolites of benzene in the liver after i.p. administration of $\left[{ }^{14} \mathrm{C}\right]$ benzene. $\left[{ }^{14} \mathrm{C}\right]$ benzene $(660 \mathrm{mg} / \mathrm{kg})$ was administered 12 and 6 hours before termination to three groups of guinea pigs on different dietary intakes of ascorbate. Ascorbate and binding values were determined for each guinea pig and the values are expressed as the mean \pm standard deviation; $p<0.01$ with respect to 0.28 to $2.63 \mu \mathrm{mol} / \mathrm{g}$ ascorbate. (From Smart and Zannoni. ${ }^{36}$ Reprinted by permission of Biochemical Pharmacology.) 


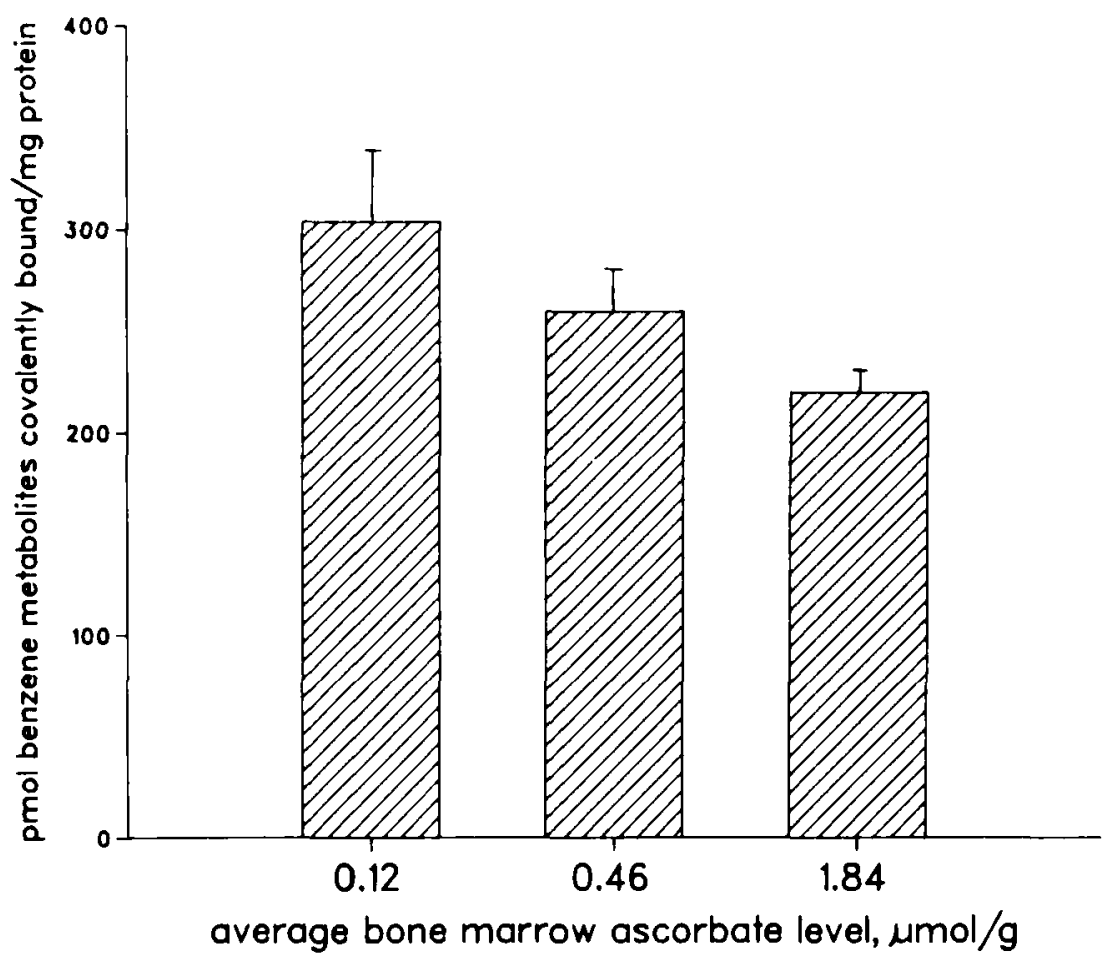

FIGURE 5. Covalent binding of the metabolites of benzene in the bone marrow after i.p. administration of $\left[{ }^{14} \mathrm{C}\right]$ benzene. $\left[{ }^{14} \mathrm{C}\right]$ Benzene $(660 \mathrm{mg} / \mathrm{kg})$ was administered 12 and 6 hours before termination to 3 groups of guinea pigs on different dietary intakes of ascorbate. Ascorbate and binding values were determined for each guinea pig and the values are expressed as the mean \pm standard deviation; $p<0.01$ with respect to 0.12 to $1.84 \mu \mathrm{mol} / \mathrm{g}$ ascorbate. (From Smart and Zannoni. ${ }^{36}$ Reprinted by permission of Biochemical Pharmacology.)

TABLE 6. Activities of Alcohol Dehydrogenase, Microsomal Ethanol-oxidizing System and the Ascorbate-Dependent Alcohol-oxidizing System with Methanol and Ethanol ${ }^{a}$

\begin{tabular}{lccc}
\hline & \multicolumn{3}{c}{$\begin{array}{c}\text { Specific Activity } \\
\text { (nmol } \mathrm{CH}_{2} \mathrm{O} \text { or } \mathrm{CH}_{2} \mathrm{CHO} / \mathrm{min} / \mathrm{mg} \text { Protein) }\end{array}$} \\
\cline { 2 - 4 } Substrate & $\begin{array}{c}\text { Alcohol } \\
\text { Dehydrogenase }\end{array}$ & $\begin{array}{c}\text { Microsomal Ethanol- } \\
\text { oxidizing System }\end{array}$ & $\begin{array}{c}\text { Ascorbate-Dependent } \\
\text { Alcohol-oxidizing System }\end{array}$ \\
\hline Methanol & $3 \pm 0.6$ & $6 \pm 1$ & $1720 \pm 200$ \\
Ethanol & $11 \pm 1.0$ & $6 \pm 1$ & $1570 \pm 140$ \\
\hline
\end{tabular}

${ }^{a}$ Assay conditions were as follows. Alcohol dehydrogenase: glycine buffer, $0.1 \mathrm{M}$, pH 9.5; $\mathrm{NAD}^{+}, 1 \mathrm{mg} / \mathrm{ml}$; guinea pig hepatic $10^{5} \mathrm{~g}$ supernatant fraction, $1.0 \mathrm{mg}$ protein; substrate, 12 $\mathrm{mM}$; total volume, $1.0 \mathrm{ml}, 37^{\circ} \mathrm{C}$. Microsomal ethanol-oxidizing system: sodium phosphate buffer, $0.1 \mathrm{M}, \mathrm{pH} 7.5$; NADPH, $2 \mathrm{mM}$; guinea pig hepatic microsomes, $1.0 \mathrm{mg}$ protein; substrate, 200 $\mathrm{mM}$; total volume $1.0 \mathrm{ml}, 37^{\circ} \mathrm{C}$. Ascorbate-dependent alcohol-oxidizing system: Tris- $\mathrm{HCl}$ buffer, $0.1 \mathrm{M}+10 \mathrm{mM} \mathrm{1,10-phenanthroline,} \mathrm{pH} 8.5$; ascorbate, $4 \mathrm{mM}$; guinea pig hepatic $10^{5} \mathrm{~g}$ supernatant fraction, $15 \mu \mathrm{g}$ protein; substrate, $800 \mathrm{mM}$; total volume, $1.0 \mathrm{ml}, 37^{\circ} \mathrm{C}$.

${ }^{b}$ Values are means of at least three experiments.

(From Susick and Zannoni. ${ }^{37}$ ) 
TABLE 7. Inhibition of the Ascorbate-Dependent Alcohol Oxidation ${ }^{a}$

\begin{tabular}{|c|c|c|c|}
\hline Assay Condition & Inhibitor & $\begin{array}{c}\text { Specific Activity } \\
\text { (nmoles } \mathrm{CH}_{2} \mathrm{O} / \mathrm{min} / \mathrm{mg} \text { ) }\end{array}$ & $\begin{array}{l}\text { Inhibition } \\
(\%)\end{array}$ \\
\hline \multicolumn{4}{|l|}{ Ascorbate } \\
\hline \multirow[t]{3}{*}{$10^{5} \mathrm{~g}$ Supernatant } & no inhibitor & 1,484 & \\
\hline & sodium azide ( $2 \mathrm{mM}$ ) & $\mathrm{nd}^{b}$ & 100 \\
\hline & 3-amino-1,2,4-triazole $(100 \mathrm{mM})$ & 547 & 63 \\
\hline \multirow[t]{3}{*}{$12,000 \mathrm{~g}$ Pellet } & no inhibitor & 760 & \\
\hline & sodium azide & nd & 100 \\
\hline & 3-amino-1,2,4-triazole & 258 & 66 \\
\hline \multirow[t]{3}{*}{ Purified catalase } & no inhibitor & 45,203 & \\
\hline & sodium azide & nd & 100 \\
\hline & 3-amino-1,2,4-triazole & 12,804 & 72 \\
\hline \multicolumn{4}{|c|}{$\mathrm{H}_{2} \mathrm{O}_{2}$ Generating System } \\
\hline \multirow[t]{3}{*}{$10^{3}$ g Supernatant } & no inhibitor & 867 & \\
\hline & sodium azide & 89 & 90 \\
\hline & 3-amino-1,2,4-triazole & 328 & 62 \\
\hline \multirow[t]{3}{*}{$12,000 \mathrm{~g}$ Pellet } & no inhibitor & 634 & \\
\hline & sodium azide & 68 & 89 \\
\hline & 3-amino-1,2,4-triazole & 144 & 77 \\
\hline \multirow[t]{3}{*}{ Purified catalase } & no inhibitor & 30,009 & \\
\hline & sodium azide & 1,944 & 94 \\
\hline & 3-amino-1,2,4-triazole & 5,468 & 82 \\
\hline
\end{tabular}

${ }^{a}$ Assay conditions: Tris- $\mathrm{HCl}$ buffer, $0.1 \mathrm{M}+1,10$-phenanthroline, $10 \mathrm{mM}, \mathrm{pH} 8.5$; ascorbate, $4 \mathrm{mM}$ or $\mathrm{H}_{2} \mathrm{O}_{2}$ generating system, $5.4 \mathrm{mg}$ glucose $+0.1 \mathrm{mg}$ glucose oxidase; guinea pig hepatic fraction, $15 \mu \mathrm{g}$ protein, or purified beef liver catalase, $0.4 \mu \mathrm{g}$ protein; methanol, $800 \mathrm{mM}$, total volume $1.0 \mathrm{ml}, 37^{\circ} \mathrm{C}$.

${ }^{b}$ Not detected.

(From Susick and Zannoni. ${ }^{37}$ )

TABLE 8. Comparison of Methanol Oxidation, $\mathrm{H}_{2} \mathrm{O}_{2}$ Production, and $\mathrm{O}_{2}$ Consumption with an $\mathrm{H}_{2} \mathrm{O}_{2}$ Generating System and the Ascorbate Oxidation System ${ }^{a}$

\begin{tabular}{lccr}
\hline \multicolumn{1}{c}{ Assay Conditions } & $\begin{array}{c}\text { Methanol } \\
\text { Oxidation } \\
\text { (nmol/min/mg) }\end{array}$ & $\begin{array}{c}\mathrm{H}_{2} \mathrm{O}_{2} \\
\text { Production } \\
\text { (nmol/min) }\end{array}$ & \multicolumn{1}{c}{\begin{tabular}{c}
\multicolumn{1}{c}{$\mathrm{O}_{2}$} \\
Consumption \\
(nmol/min)
\end{tabular}} \\
\hline $\mathrm{H}_{2} \mathrm{O}_{2}$ generating system & $223 \pm 14(3)$ & $3.9 \pm 0.9(3)$ & $4.3 \pm 0.6(5)$ \\
Ascorbate & $247 \pm 22(3)$ & $6.9 \pm 0.4(4)$ & $23.9 \pm 1.0(6)$ \\
\hline
\end{tabular}

assay conditions were as follows. Methanol oxidation: Tris- $\mathrm{HCl}$ buffer, $0.1 \mathrm{M}+1,10-$ phenanthroline, $10 \mathrm{mM}, \mathrm{pH} 8.5$; ascorbate, $1 \mathrm{mM}$, or $\mathrm{H}_{2} \mathrm{O}_{2}$ generating system, $30 \mathrm{mM}$ glucose $+0.02 \mathrm{mg}$ glucose oxidase; guinea pig hepatic $10^{\mathrm{s}} \mathrm{g}$ supernatant fraction, $15 \mu \mathrm{g}$ protein; methanol, $800 \mathrm{mM}$; total volume, $1.0 \mathrm{ml}, 25^{\circ} \mathrm{C}$. $\mathrm{H}_{2} \mathrm{O}_{2}$ production: Tris- $\mathrm{HCl}$ buffer, $0.1 \mathrm{M}+1,10$-phenanthroline, $10 \mathrm{mM}, \mathrm{pH} 8.5$; ascorbate, $1 \mathrm{mM}$, or $\mathrm{H}_{2} \mathrm{O}_{2}$ generating system, $30 \mathrm{mM}$ glucose + $0.04 \mathrm{mg}$ glucose oxidase; boiled guinea pig hepatic $10^{5} \mathrm{~g}$ supernatant fraction, $30 \mu \mathrm{g}$ protein; total volume $2.0 \mathrm{ml}, 25^{\circ} \mathrm{C}$. $\mathrm{O}_{2}$ consumption: Tris- $\mathrm{HCl}$ buffer, $0.1 \mathrm{M}+1,10$-phenanthroline, 10 $\mathrm{mM}, \mathrm{pH} 8.5$; ascorbate, $1 \mathrm{mM}$, or $\mathrm{H}_{2} \mathrm{O}_{2}$ generating system, $30 \mathrm{mM}$ glucose $+0.03 \mathrm{mg}$ glucose oxidase; boiled guinea pig hepatic $10^{5} \mathrm{~g}$ supernatant fraction, $22.5 \mu \mathrm{g}$ protein; total volume, 1.5 $\mathrm{ml}, 25^{\circ} \mathrm{C}$. Data are means $\pm \mathrm{SD}$. Numbers in parentheses represent number of experiments.

(Modified from Susick and Zannoni. ${ }^{57}$ ) 
TABLE 9. Effect of Hepatic Ascorbic Acid Concentration on Indices of Acute Ethanol Toxicity $^{a}$

\begin{tabular}{|c|c|c|c|c|}
\hline & $\begin{array}{c}\text { SGOT } \\
\text { (Units/ml } / \mathrm{ml}^{\text {m }}\end{array}$ & $\begin{array}{c}\text { SGPT } \\
\text { (Units/ml) }\end{array}$ & $\begin{array}{c}\text { Serum } \\
\text { Triglycerides } \\
(\mathrm{mg} / 100 \mathrm{ml})\end{array}$ & $\begin{array}{c}\text { Liver } \\
\text { Weight : } \\
\text { Body } \\
\text { Weight } \\
(\mathrm{mg} / \mathrm{g})\end{array}$ \\
\hline \multicolumn{5}{|l|}{$\begin{array}{l}\text { Hepatic Ascorbate } \\
\text { (mg/100 g liver) }\end{array}$} \\
\hline $\begin{array}{l}1 \text { to } 16 \\
17 \text { to } 36 \\
p \text { Value }\end{array}$ & $\begin{aligned} 281 & \pm 140(14) \\
111 & \pm 26(7) \\
& <0.01\end{aligned}$ & $\begin{array}{l}64 \pm 24(14) \\
53 \pm \underset{\mathrm{ns}^{d}}{ \pm 12}\end{array}$ & $\begin{array}{c}200 \pm 86(12) \\
213 \pm \underset{n s}{101}(7)\end{array}$ & $\begin{aligned} 46 & \pm 7(14) \\
40 & \pm 2(7) \\
& <0.05\end{aligned}$ \\
\hline Baseline before Alcohol & $22 \pm 9$ & $17 \pm 8$ (21) & $121 \pm 37$ (19) & \\
\hline
\end{tabular}

${ }^{a}$ Values represent means $\pm \mathrm{SD}$, with number of animals in parentheses, after $4.0 \mathrm{~g}$ ethanol/ kg i.p. Baseline values taken before ethanol administration were not affected by ascorbate concentration and were combined.

${ }^{\circ} 1$ unit $=4.82 \times 10^{-4} \mu$ moles glutamate formed $/ \mathrm{min}$.

' $p$ values calculated from a two-sided Student's $t$-test.

${ }^{d}$ not significant, $p>0.05$.

(From Susick and Zannoni. ${ }^{\text {s8 }}$ )

TABLE 10. Serum Enzymes and Liver Weight to Body Weight Ratios after Chronic Alcohol Consumption"

\begin{tabular}{|c|c|c|c|c|}
\hline & \multicolumn{2}{|c|}{ Low Ascorbic Acid Diet ${ }^{b}$} & \multicolumn{2}{|c|}{ High Ascorbic Acid Diet } \\
\hline & No Alcohol & Alcohol & No Alcohol & Alcohol \\
\hline SGOT (units $/ \mathrm{ml}$ ) & $42 \pm 8(5)$ & $92 \pm 34(8)^{* *}$ & $32 \pm 12(6)$ & $47 \pm 12(12)^{*}$ \\
\hline SGPT (units / ml) ${ }^{d}$ & $15 \pm 9(5)$ & $52 \pm 29(8)^{*}$ & $14 \pm 5(6)$ & $24 \pm 11(12)$ \\
\hline$\frac{\text { Liver Weight }}{\text { Body Weight }}(\mathrm{mg} / \mathrm{gram})$ & $41 \pm 3(6)$ & $42 \pm 10(9)$ & $43 \pm 7$ (6) & $38 \pm 10(13)$ \\
\hline
\end{tabular}

${ }^{\circ}$ Values represent the mean \pm SD with number of animals in parentheses.

${ }^{b}$ Mean hepatic ascorbic acid concentration: no alcohol, $30 \pm 9 \mathrm{mg} / 100 \mathrm{~g}$ protein; alcohol, $20 \pm 6 \mathrm{mg} / 100 \mathrm{~g}$ protein.

' Mean hepatic ascorbic acid concentration: no alcohol, $130 \pm 34 \mathrm{mg} / 100 \mathrm{~g}$ protein; alcohol, $120 \pm 28 \mathrm{mg} / 100 \mathrm{~g}$ protein.

${ }^{d} 1$ unit $=4.82 \times 10^{-4} \mu$ moles glutamate formed $/ \mathrm{min}$.

* $p<0.05$ from nonalcohol control group.

** $p<0.01$ from nonalcohol control group.

(From Susick et al. ${ }^{60}$ ) 

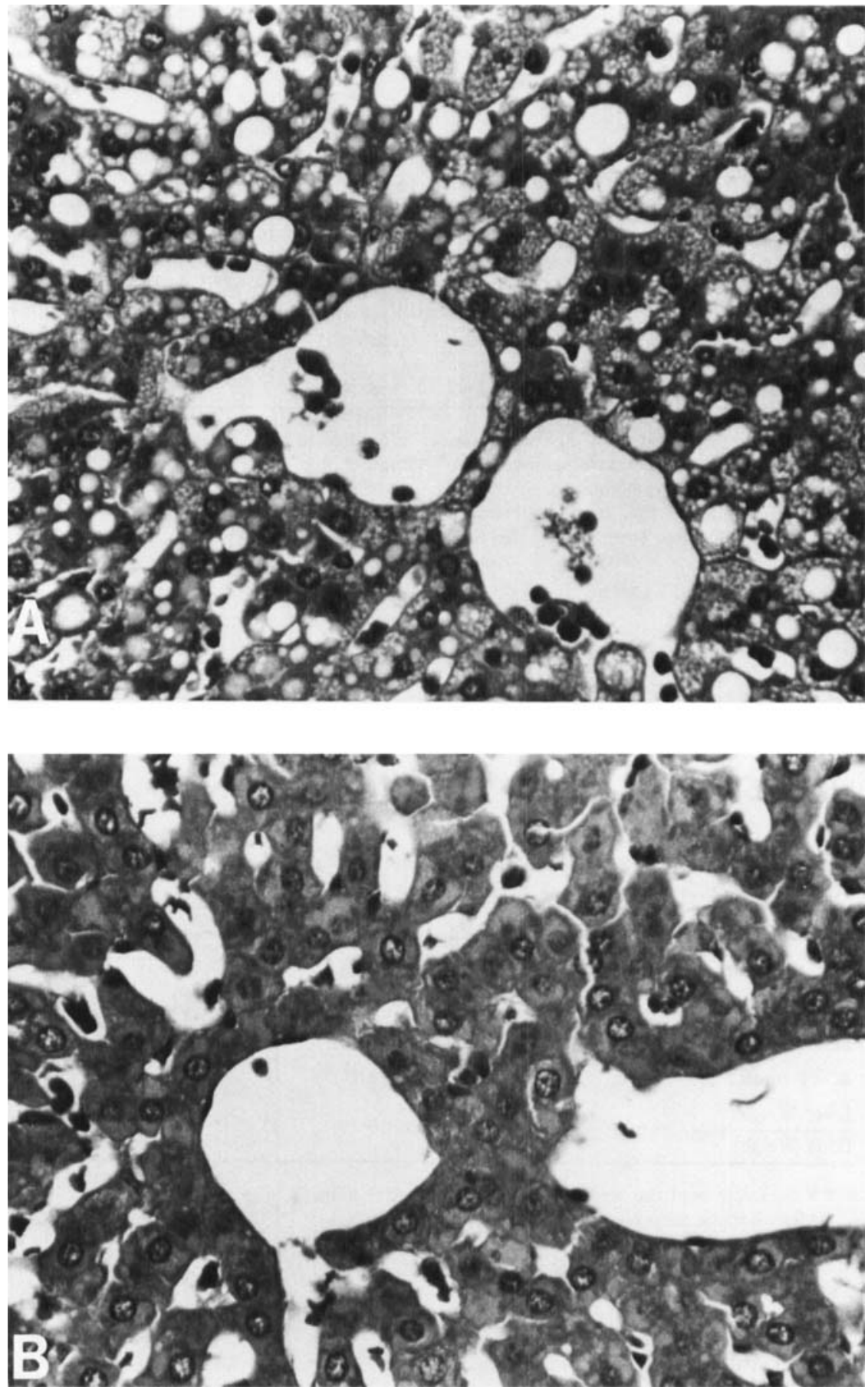
With regard to behavioral tests, ethanol consumption impaired motor coordination and the vitamin significantly reduced this impairment (FIG. 9). Thirteen subjects had a greater than $20 \%$ difference in motor coordination after ascorbic acid pretreatment. Eleven of these thirteen subjects had a $21-50 \%$ improvement after vitamin pretreatment; two had a decrease of $48 \%$ and $56 \%$. Of the remaining seven subjects, one had an improvement in motor coordination of $14 \%$ and six had a decrease from $1 \%$ to $20 \%$. Pretreatment with the vitamin also protected against decrease in color discrimination after ethanol (FIG. 10). Ten subjects had a greater than $20 \%$ difference in color discrimination after ascorbic acid pretreatment. Nine of these had a $20-100 \%$ improvement. The remaining three subjects had a 10-20\% decrease in color discrimination. There was no statistically significant effect of ascorbic acid, however, on intellectual function.

\section{DISCUSSION}

The participation of ascorbic acid in the major xenobiotic metabolizing systems requiring endoplasmic reticulum electron transport is rather specific. The depletion of the vitamin does not involve an impairment leading to a general membrane alteration. Cytochrome P-450, a heme protein, and the flavin monooxygenase, a nonheme, FAD-requiring enzyme, are significantly decreased in deficiency. ${ }^{1-24}$ On the other hand, microsomal $b_{3}$ reductase, a FAD-requiring enzyme, and microsomal cytochrome $b_{5}$, a heme protein, are not affected by the depletion of the vitamin. With regard to the cytochrome P-450 mixed function monooxygenase and the flavin monooxygenase enzyme, the participation of ascorbic acid shares some similarities but also some differences. With either system there are no significant alterations between enzyme prepared from vitamin $C$ or supplemented animals in the apparent affinity of drug substrates or cofactors. ${ }^{6,7,15,22.24}$ In addition, with purification there is a significant decrease in the quantity of cytochrome $\mathrm{P}-450$ as well as the flavin monooxygenase. ${ }^{24}$ With regard to cytochrome $\mathrm{P}-450$, the decrease involves three specific heme isozymes while others are unaltered. ${ }^{19}$ Also, inhibitor studies with ferrous iron chelators and substrate binding information indicate that the vitamin's participation, most likely, is at the heme-ferrous ion level, and specifically with those isozymes most affected by the deficiency. ${ }^{16}$

To date, the observed decrease in the quantity of FMO could be more general, or for that matter involve a disaggregation of monomeric forms of FMO resulting in a loss of recoverable enzyme protein. ${ }^{22.24}$ In addition to a decrease in the quantity of FMO protein, vitamin C deficiency also resulted in purified FMO fractions, which had an obligatory need of exogenous FAD for optimal activity. Perhaps the binding site of FAD to apo-enzyme is jeopardized, leading to disaggregation with subsequent decrease in viable enzyme. In keeping with this, FMO purified from vitamin-C-deficient animals is highly unstable and vulnerable to marked substrate inhibition. This is not the case with purified cytochrome P-450 isolated from vitamin-C-deficient animals.

FIGURE 6. Photomicrographs of the liver, hematoxylin and eosin, magnification $470 \times$. (A) From animal on the low ascorbic acid diet, after 14 weeks of ethanol feeding. Note the marked, diffuse vacuolar change in hepatocytes, indicative of steatosis. (B) From animal on the high ascorbic acid diet, after 14 weeks of ethanol feeding. In contrast to $A$, there is no steatosis. (From Susick et al. ${ }^{\infty}$ Reprinted by permission of Toxicology and Applied Pharmacology.) 


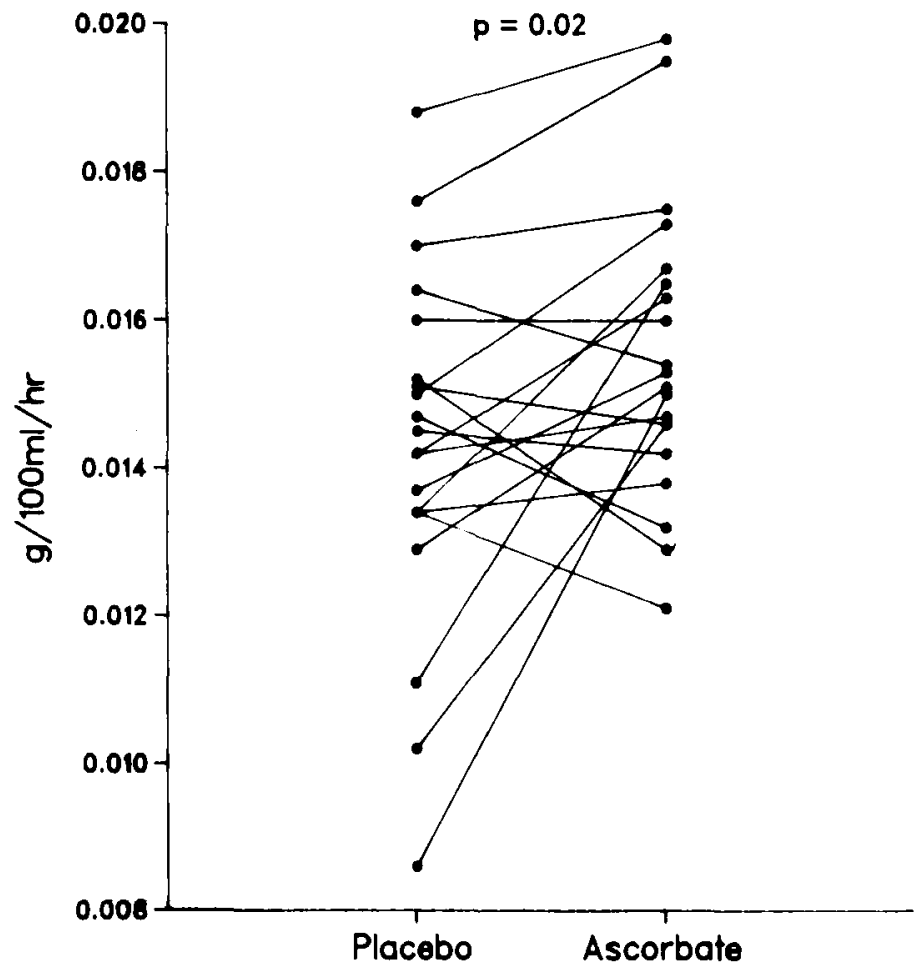

FIGURE 7. Effect of ascorbic acid pretreatment on blood ethanol clearance after an acute dose of ethanol in 20 subjects. Ascorbic acid or placebo (lactose) was given for 2 weeks prior to the alcohol; $1.0 \mathrm{gram}$ of ascorbic acid or placebo was taken five times a day. On the test day 0.95 gram ethanol $/ \mathrm{kg}$ body weight was taken orally as a $30 \%$ solution in ginger ale over a $2 \frac{1}{2}$-h period. (From Susick and Zannoni. ${ }^{39}$ Reprinted by permission of Clinical Pharmacology and Therapeutics.)

Furthermore, the decrease in FMO activity in vitamin $\mathrm{C}$ deficiency was enhanced by a concomitant loss of $10-15 \%$ body weight, which was not found with cytochrome P.450. ${ }^{23}$ The in vivo consequences of a decreased capacity of these two major electron transport systems will obviously depend upon the particular xenobiotic under investigation, that is, the potential toxicity of the substrate itself or its subsequent metabolites. In addition, since both electron transport systems are affected in vitamin C deficiency, their contribution to metabolism and the possibility of forming toxic intermediates will rely heavily on the degree to which particular species of either transport system becomes rate limiting. Although it is difficult to predict the ultimate consequences of jeopardized electron transport metabolic systems by a biochemical in vitro analysis, an in vivo model is at hand whereby a variety of xenobiotics could be tested under depletion of the vitamin and an examination of any toxicological consequences documented.

In addition to the effect of ascorbic acid on the important electron transport systems, MFO and FMO, the vitamin partakes via its reductive property in preventing quinoid-type reactive intermediates from covalent binding to macromolecular proteins. $^{25,28,30,32-36,48}$ This participation was illustrated in the metabolic transformation of 
benzene or phenol, which results in electrophilic reactive quinone species, the latter undergoing reduction by the vitamin. ${ }^{34}$ Although the precise damaging intermediate of benzene or phenol resulting in myelotoxicity remains to be elucidated-it may be a hydroxyl cyclohexadienyl radical formed from benzene ${ }^{49}$ or a semiquinone or quinone type metabolite of phenol-the vitamin affords in vitro protection..$^{35}$ In keeping with these findings, when the dietary ascorbic acid was varied in the guinea pig in vivo, the ensuing covalent binding of benzene metabolites to hepatic or bone marrow tissue was inversely related to the concentration of the vitamin found in these tissues. ${ }^{36}$ Both the in vitro and in vivo effect of varying amounts of ascorbic acid on covalent binding with benzene, however, was less than when phenol was used as a substrate. For example, ascorbate is capable of inhibiting the in vitro covalent binding of phenol by over $90 \%$ compared to $35 \%$ with benzene as a substrate. Similarly, the in vivo covalent binding with an i.p. administration of benzene decreased $30 \%$ in the bone marrow of animals on a high intake of the vitamin. ${ }^{36}$ This is suggestive that the most potent species of benzene transformation may not be oxidized forms of hydroquinone, ca-

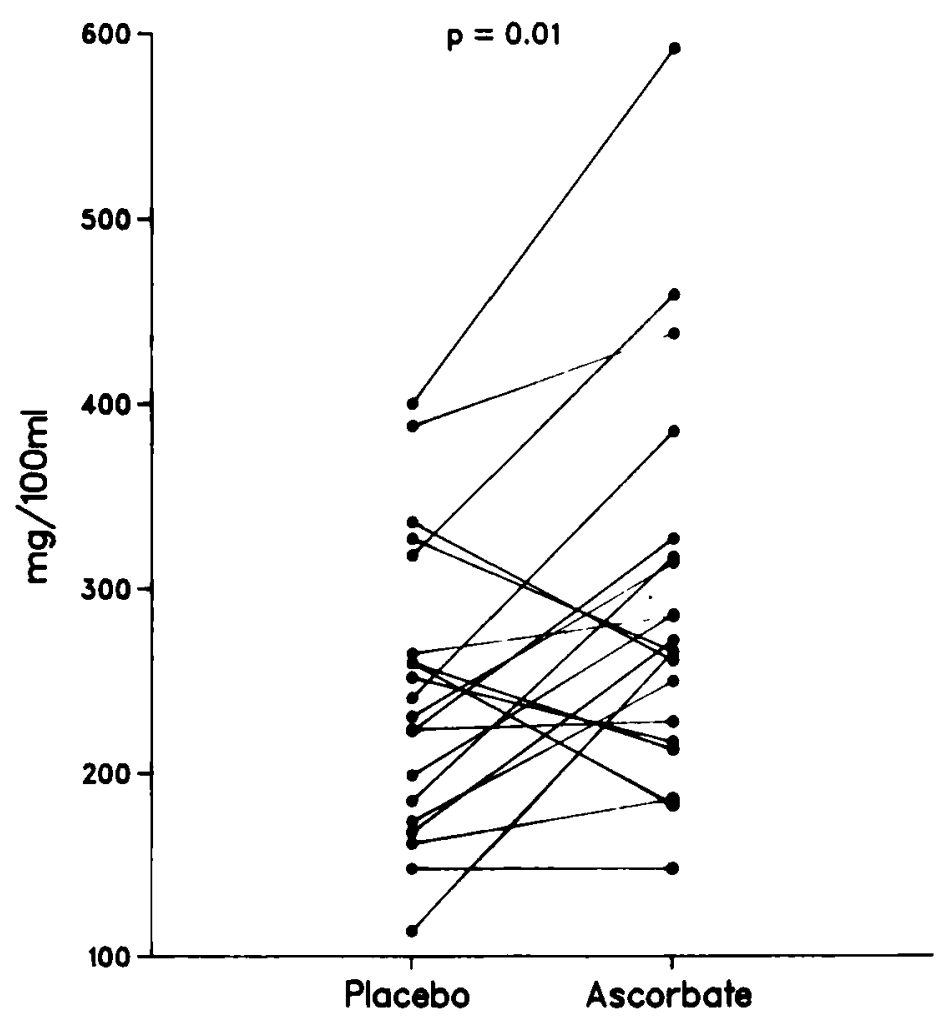

FTGURE 8. Effect of ascorbic acid pretreatment on serum triglyceride levels after an acute dose of ethanol in 20 subjects. Ascorbic acid or placebo (lactose) was given for 2 weeks prior to the alcohol; $1.0 \mathrm{gram}$ of ascorbic acid or placebo was taken five times a day. On the test day 0.95 gram ethanol $/ \mathrm{kg}$ body weight was taken orally as a $30 \%$ solution in ginger ale over a $2 \frac{1}{2}-\mathrm{h}$ period. (From Susick and Zannoni. ${ }^{99}$ Reprinted by permission of Clinical Pharmacology and Therapeutics.) 


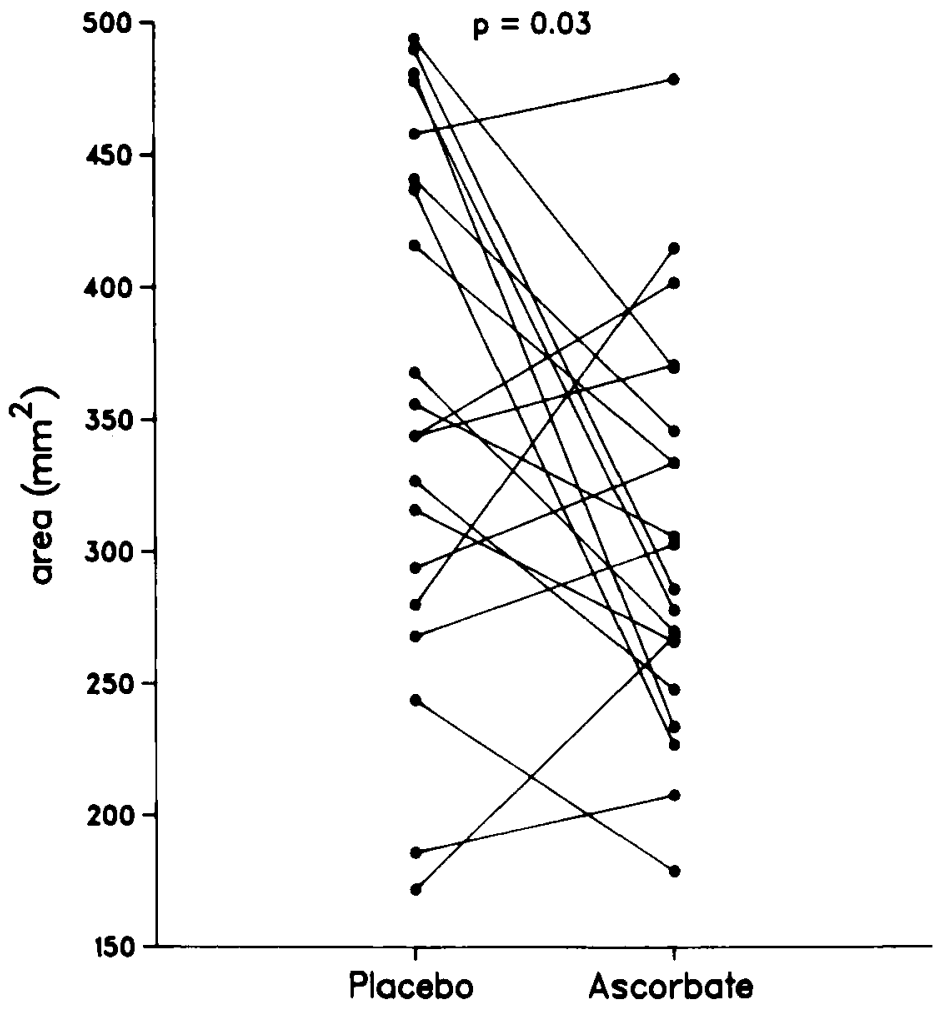

FIGURE 9. Effect of ascorbic acid pretreatment on motor coordination after an acute dose of ethanol in 20 subjects. Ascorbic acid or placebo (lactose) was given for 2 weeks prior to the alcohol; $1.0 \mathrm{gram}$ of ascorbic acid or placebo was taken five times a day. On the test day 0.95 gram ethanol $/ \mathrm{kg}$ body weight was taken orally as a $30 \%$ solution in ginger ale over a $2 \frac{1}{2}-\mathrm{h}$ period. (From Susick and Zannoni. ${ }^{39}$ Reprinted by permission of Clinical Pharmacology and Therapeutics.)

techol, or phenol since the vitamin is extremely effective in reducing these metabolites and consequently preventing their interaction with macromolecular tissue sites. On the other hand, another possibility exists that the cellular distribution of the vitamin is not at a substantial concentration at the precise macromolecular site of interaction with metabolites of benzene. Consideration should be given, however, to the findings that modulation of the intake of the vitamin can alter the covalent binding of benzene metabolites in the bone marrow in vivo, which is the target tissue of benzene toxicity.

In the United States at least 10 million people suffer from alcohol abuse. An estimated 205,000 deaths every year are attributable to that abuse, the causes ranging from highway fatalities to cirrhosis. ${ }^{6 t}$ In large urban areas of the United States, cirrhosis has become the third most common cause of all deaths in the age group 25 to 65 years. ${ }^{65}$ The ability of any agent to influence the effect of alcohol on the body is of importance. In this regard, vitamin $\mathrm{C}$ has been demonstrated to influence ethanol metabolism, toxicity, and behavioral impairment in man and animals. . $^{1,55-56,58-61,66}$

Ascorbic acid pretreatment enhanced ethanol clearance from the blood in healthy human subjects. ${ }^{59,66}$ We have described and characterized an ascorbic-acid-dependent 
alcohol oxidizing system that is catalyzed by catalase. ${ }^{57}$ In this system, ascorbic acid generated a peroxide that is utilized by catalase in a peroxidatic oxidation of the alcohol. The ability of ascorbic acid pretreatment to enhance blood ethanol clearance may be due to its ability to supply peroxide and thus allow catalase to contribute to ethanol oxidation.

It is well established that ethanol affects lipoprotein metabolism and that an acute dose increases levels of serum and hepatic triglycerides. ${ }^{67-69}$ Ethanol causes a number of events to occur that lead to increased hepatic fat levels, e.g., a stress-induced mobilization of fat from adipose tissues, a decrease in the rate of fatty acid oxidation, an increase in the rate of fatty acid synthesis, and an increase in the esterification of fatty acids to triglycerides. In addition, ethanol inhibits export of fat from the liver by impairing the synthesis and secretion of very low-density lipoproteins (VLDL), the export form of triglycerides. Ascorbic acid pretreatment in human subjects caused an increase in serum triglyceride levels. ${ }^{59}$ The possibility that the vitamin increases the rate of fat transport out of the liver should be considered. This could be accomplished by a stimulation of the synthesis or secretion of the VLDL or by prevention

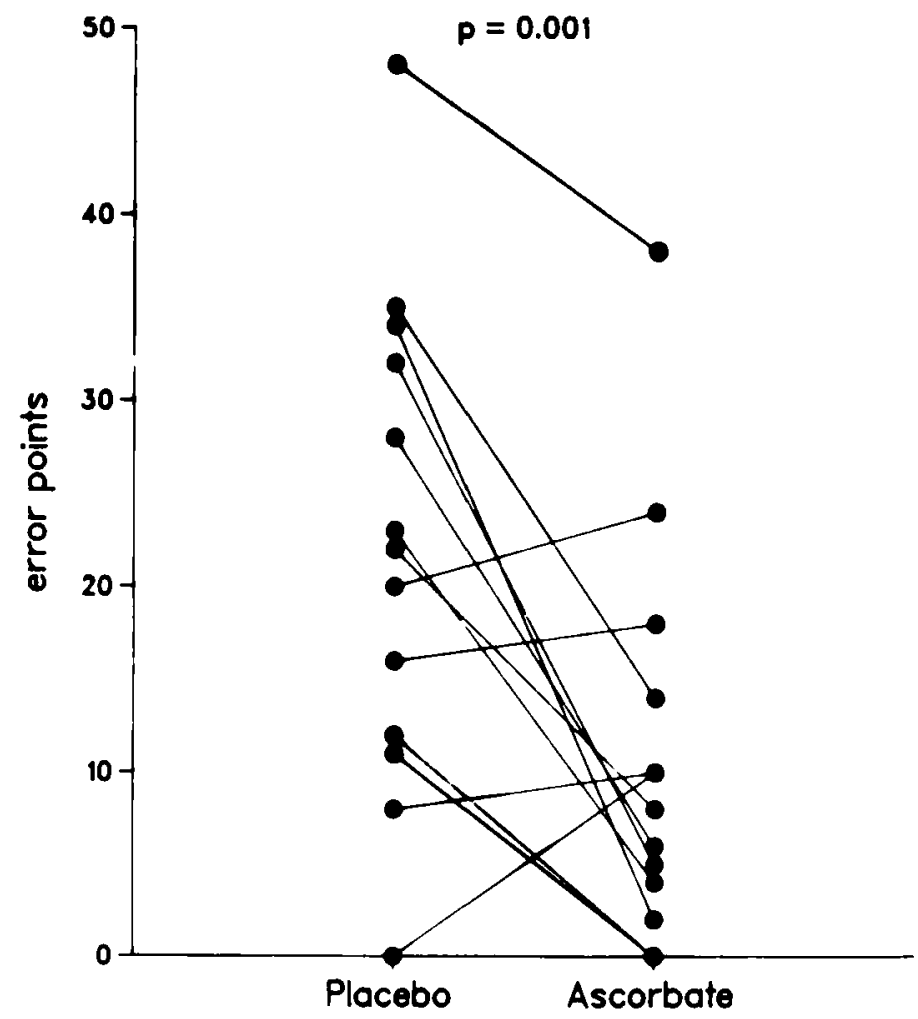

FIGURE 10. Effect of ascorbic acid pretreatment on color discrimination after an acute dose of ethanol in 13 subjects. Ascorbic acid or placebo (lactose) was given for 2 weeks prior to the alcohol; $1.0 \mathrm{gram}$ of ascorbic acid or placebo was taken five times a day. On the test day 0.95 gram ethanol $/ \mathrm{kg}$ body weight was taken orally as a $30 \%$ solution in ginger ale over a $2 \frac{1}{2}-\mathrm{h}$ period. (From Susick and Zannoni. ${ }^{39}$ Reprinted by permission of Clinical Pharmacology and Therapeutics.) 
of alcohol's impairment of these processes. This mechanism would result in less fat accumulation in the liver. In keeping with this, in vivo guinea pig studies have demonstrated that ascorbic acid pretreatment results in less hepatic steatosis after chronic ethanol consumption. ${ }^{60}$ Ascorbic acid may also protect the liver against direct ethanol toxicity, as evidenced in acute and chronic in vivo guinea pig studies where ascorbic acid protected against elevated SGOT and SGPT levels, indices of increased permeability and/or necrosis of hepatocytes. ${ }^{59,60}$

The participation of ascorbic acid in neurochemical events is of current interest. Its involvement in $\mathrm{Na}^{+}$and $\mathrm{K}^{+}$transport and metabolism of neurotransmitters, including the synthesis of catecholamines, storage of norepinephrine, and regulation of dopaminergic transmission, have been reported. ${ }^{70-72}$ In addition, the vitamin has been implicated in modulating the behavioral effects of antipsychotic drugs by influencing their binding to the dopamine receptor. ${ }^{3}$ With regard to ethanol's impairment of behavior, ascorbic acid has been shown to prevent impaired swimming in mice caused by an intoxicating dose of ethanol. ${ }^{55}$ The protective effect of ascorbic acid pretreatment on impaired motor coordination demonstrated in the clinical study (FIG. 9) supports a neurochemical role for the vitamin. The protective effect is not due to altered blood ethanol concentrations, since ascorbic acid pretreatment had no effect on ethanol concentrations at the time the behavioral tests were administered. The mechanism of the protective action, be it through stabilization of the neuronal membrane, an effect on $\mathrm{Na}^{+} / \mathrm{K}^{+}$transport, an effect on the synthesis, storage, release or binding of the neurotransmitters, or an as yet unknown mechanism, remains to be determined.

Ascorbic acid is capable of influencing both biochemical and behavioral changes caused by an acute dose of ethanol in man. The influence of ascorbic acid pretreatment, although not observed in every subject, was greatest in those subjects with the largest alcohol impairment of behavior and in those subjects with the slowest rates of ethanol elimination after placebo pretreatment. The results of the clinical study coupled with the animal studies suggest that ascorbic acid may be of value in protecting against some harmful consequences of alcohol consumption in certain individuals. In addition, the determination of the exact mechanisms by which ascorbic acid acts may lead to the elucidation of important new biological roles for the vitamin.

\section{CONCLUSIONS}

Ascorbic acid is involved in the metabolism and detoxification of xenobiotics, in the hepatic microsomal electron transport system, in protection against binding of reactive intermediates, and in the metabolism of alcohol and protection against alcohol toxicity. Its deficiency results in a decrease of the flavin monooxygenase system (50\%). There is a decrease in recoverable enzyme and an obligatory requirement for exogenous FAD. In addition, the vitamin, through its reductive properties, affords $75 \%$ protection against macromolecular protein binding of "reactive" intermediates of benzene or phenol. Furthermore, ascorbic acid participates in alcohol metabolism by generating a peroxide that is utilized by catalase to oxidize alcohol. The vitamin protects against acute and chronic alcohol toxicity. SGOT levels are lowered (50\%) and fatty infiltration and necrosis of hepatocytes are minimized. In clinical studies with an acute dose of ethanol, vitamin pretreatment enhanced ethanol clearance (11-74\%), increased serum triglycerides (33-133\%), and was beneficial in behavioral responses of motor coordination and color discrimination in $50 \%$ of the subjects. 


\section{REFERENCES}

1. Richards, R. K., K. Kueter \& T. 1. Klatt. 1941. Effect of vitamin C deficiency on action of different types of barbiturates. Proc. Soc. Exp. Biol. Med. 48: 403-409.

2. AXElRoD, J., S. UdENFRIEND \& B. B. BrodiE. 1954. Ascorbic acid in aromatic hydroxylation. III. Effect of ascorbic acid on hydroxylation of acetanilide, aniline and antipyrine in vivo. J. Pharmacol. Exp. Ther. 111: 176-181.

3. Conney, A. H., G. A. Bray, C. Evans \& J. J. Burns. 1961. Metabolic interactions between L-ascorbic acid drugs. Ann. N.Y. Acad. Sci. 92: 115-127.

4. Kato, R. A., Takanaka \& T. Oshima. 1969. Effect of vitamin C deficiency on metabolism of drugs and NADPH-linked electron transport system in liver microsomes. Jpn. J. Pharmacol. 19: 25-33.

5. Leber, H., E. Degkwitz \& H. Staudinger. 1969. Untersuchungen zum Einfluss der Ascorbinaure auf die Aktivitat und die Biosynthese mischfunktioneller Oxygenasen sowie den Gehalt an Hamoproteiden in der Mikrosomenfraktion der Meerschweinchenleber. Hoppe-Seyler's Z. Physiol. Chem. 350: 439-455.

6. ZANNONI, V. G., E. J. FLYNN \& M. LYNCH. 1972. Ascorbic acid and drug metabolism. Biochem. Pharmacol. 21: 1377-1392.

7. ZANNONI, V. G. \& M. M. LYNCH. 1973. The role of ascorbic acid in drug metabolism. Drug Metab. Rev. 2: 57-69.

8. GundermanN, K., E. Degkwitz \& H. Staudinger. 1973. Mischfunktionelle Oxygenierung von $(+)$ und $(-)$ Hexobarbital und spektrale Anderungen des Cytochrome P-450 in der Leber ascorbinsaurefrei ernahrter Meerschweinchen. Hoppe-Seyler's Z. Physiol. Chem. 354: 238-242.

9. GiNTER, E. 1973. Cholesterol: Vitamin C controls its transformation to bile acids. Science 179: $702-704$.

10. Gundermann, K., E. Degkwitz \& H. Staudinger. 1973. Mixed function oxygenation of $(+)$ and $(-)$ hexobarbital and spectral changes of cytochrome P-450 in liver of guinea pigs fed without L-ascorbic acid. Hoppe-Seyler's Z. Physiol. Chem. 354: 238-242.

11. DeGKwITZ, E. \& K. S. KIM. 1973. Comparative studies on the influence of L-ascorbic acid, D-arabino-ascorbate and 5-x-D-gluconate on the amounts of cytochrome P-450 and $b_{3}$ in liver microsomes of guinea pigs. Hoppe-Seyler's Z. Physiol. Chem. 354: 555-561.

12. Zannoni, V. G., M. M. LyNCh \& P. H. Sato. 1974. In Perinatal Pharmacology: Problems and Priorities. J. Dancis \& J. C. Hwang, Eds.: 131-147. Raven Press. New York.

13. DegKwitz, E., S. Walsch \& M. Dubberstein. 1974. Influence of L-ascorbate on the concentrations of microsomal cytochrome P-450 and cytochrome $b_{s}$ in adrenals, kidney and spleen of guinea pigs. Hoppe-Seyler's Z. Physiol. Chem. 355: 1152-1158.

14. Sato, P. H. \& V. G. ZanNoni. 1974. Stimulation of drug metabolism by ascorbic acid in weanling guinea pigs. Biochem. Pharmacol. 23: 3121-3127.

15. ZanNoni, V. G. \& P. H. SAto. 1975. Effects of ascorbic acid on components of liver microsomal drug metabolizing enzymes. Ann. N.Y. Acad. Sci. 258: 119-131.

16. Sato, P. H. \& V. G. ZanNoni. 1976. Ascorbic acid and hepatic drug metabolism. J. Pharmacol. Exp. Ther. 198: 295-307.

17. Rikans, L. E., C. R. Smith \& V. G. Zannoni. 1977. Ascorbic acid and heme synthesis in deficient guinea pig liver. Biochem. Pharmacol. 26: 797-799.

18. Kuenzig, W., V. TKaczevski, J. J. Kamm, A. H. Conney \& J. J. Burns. 1977. The effect of ascorbic acid deficiency on extrahepatic microsomal metabolism of drugs and carcinogens in the guinea pig. J. Pharmacol. Exp. Ther. 201: 527-533.

19. Rikans, L. E., C. R. Smith \& V. G. ZanNoni. 1978. Ascorbic acid and cytochrome P450. J. Pharmacol. Exp. Ther. 204: 702-713.

20. ZanNoni, V. G., E. HolszTYNSKa \& S. S. LaU. 1982. Biochemical functions of ascorbic acid in drug metabolism. In Ascorbic Acid: Chemistry, Metabolism and Uses. P. A. Seib \& B. M. Tolbert, Eds.: 349-368. American Chemical Society. Washington, D.C.

21. Zannoni, V. G., R. L. Susick \& R. C. Smart. 1984. Ascorbic acid as it relates to the metabolism of drugs and environmental chemicals. In Nitrition in the 20th Century, Vol. 13. M. Winick, Ed.: 21-35. John Wiley \& Sons. New York.

22. Brodfuehrer, J. I. \& V. G. ZaNNONI. 1987. Ascorbic acid deficiency and the flavincontaining monooxygenase. Biochem. Pharmacol. 35: 637-644. 
23. Brodfuehrer, J. I. \& V. G. ZANNONI. 1987. Modulation of the flavin-containing monooxygenase by ascorbic acid and food restriction. J. Nutrition. 117: 286-291.

24. Brodfuehrer, J. I. 1986. Ascorbic acid and the flavin-containing monooxygenase. Ph.D. thesis, University of Michigan.

25. Houston, J. B. \& G. Levy. 1976. Drug biotransformation interaction in man. VI. Acetaminophen and ascorbic acid. J. Pharm. Sci. 65: 1218-1221.

26. Hinson, J. A., S. D. Nelson \& J. R. Mitchell. 1977. Studies on the microsomal formation of arylating metabolites of acetaminophen and phenacetin. Mol. Pharmacol. 13: 625-633.

27. Hinson, J. A., L. R. Pohl \& J. R. Gillette. 1979. N-Hydroxyacetaminophen: A microsomal metabolite of $\mathrm{N}$-hydroxyphenacetin but apparently not of acetaminophen. Life Sci. 24: 2133-2138.

28. Corcoran, G. B., J. R. Mitchell, Y. N. Vaishnav \& E. C. Horning. 1980. Evidence that acetaminophen and $\mathrm{N}$-hydroxyacetaminophen form a common arylating intermediate, N-acetyl-p-benzoquinoneimine. Mol. Pharmacol. 18: 536-542.

29. Hinson, J. A., L. R. Pohl, T. J. Monks, J. R. Gillette \& F. P. Guengerich. 1980. 3-Hydroxyacetaminophen: A microsomal metabolite of acetaminophen. Evidence against an epoxide as the reactive metabolite of acetaminophen. Drug Metab. Dispos. 8: 289-294.

30. Lake, G., R. A. Harris, J. C. Phillips \& S. D. Gangolli. 1981. Studies on the effects of $\mathbf{L}$-ascorbic acid on acetaminophen-induced hepatotoxicity. Toxicol. Appl. Pharmacol. 60: 229-240.

31. Gillette, J. R., S. D. Nelson, G. J. Mulder, D. J. Jollow, J. R. Mitchell, L. R. POHL \& J. A. HINSON. 1982. Formation of chemically reactive metabolites of phenacetin and acetaminophen. In Biological Reactive Intermediates. II. Chemical Mechanisms and Biological Effects (part B). R. Snyder, D. V. Parke, J. J. Kocsis, G. Gibson \& D. J. Jollow, Eds.: 931 -950. Plenum Press. New York.

32. ZanNoni, V. G., E. G. Marker \& S. S. LAU. 1982. Hepatic bromobenzene epoxidation and binding: Their prevention by ascorbyl palmitate. J. Drug Nutrient Interact. 1: 193-204.

33. MiLler, M. G. \& D. J. Jollow. 1983. Effect of ascorbic acid on acetaminophen-induced hepatotoxicity and covalent binding in hamsters. Drug Metabol. Dispos. 12: 271-279.

34. SMART, R. C. \& V. G. ZANNONI. 1984. DT-diaphorase and peroxidase influence the covalent binding of the metabolites of phenol, the major metabolite of benzene. Mol. Pharmacol. 26: $105-111$.

35. SMART, R. C. \& V. G. ZANNONI. 1985. Effect of ascorbate on covalent binding of benzene and phenol metabolites to isolated tissue preparations. Toxicol. Appl. Pharm. 77: 334-343.

36. SMART, R. C. \& V. G. ZANNONI. 1986. Effect of dietary ascorbate on covalent binding of benzene to bone marrow and hepatic tissue in vivo. Biochem. Pharmacol. 35: 3180-3182.

37. SNYDER, R. \& J. J. Kocsis. 1975. Current concepts of chronic benzene toxicity. CRC Crit. Rev. Toxicol. 3: 265-288.

38. SNyder, R. S., S. L. Longacre, C. M. Witmer, J. J. Kocsis, L. S. ANdrews \& E. W. LEE. 1981. Biochemical toxicology of benzene. In Reviews in Biochemical Toxicology, Vol. 3. E. Hodgson, J. R. Bend \& R. M. Philpot, Eds.: 123-153. Elsevier/North-Holland. New York.

39. Goldstein, B. D. 1977. Hematotoxicity in humans. In Benzene Toxicity, a Critical Evaluation. J. Toxicol. Environ. Health (Suppl.) 2: 69-105.

40. LEE, E. W., J. J. Kocsis \& R. SNYDER. Dose dependent inhibition of ${ }^{59} \mathrm{Fe}$ incorporation into erythrocytes after a single dose of benzene. Res. Commun. Chem. Pathol. Pharmacol. 5: $547-550$.

41. Andrews, L. S., E. W. LeE, C. M. Witmer, J. J. Kocsis \& R. SNYder. 1977. Effects of toluene on the metabolism, disposition and hemopoietic toxicity of ${ }^{14} \mathrm{C}$-benzene. Biochem. Pharmacol. 26: 293-300.

42. Nomiyama, K. 1962. Studies on the poisoning by benzene and its homologues: Oxidation rate of benzene and benzene poisoning. Med. J. Shinshu Univ. 7: 41-48.

43. SAmmetT, D., E. W. LeE, J. J. Kocsis \& R. SNYDER. 1979. Partial hepatectomy reduces both metabolism and toxicity of benzene. J. Toxicol. Environ. Health 5: 785-792.

44. BolCSAK, L. E. \& D. E. NerLaND. 1983. Inhibition of erythropoiesis by benzene and benzene metabolites. Toxicol. Appl. Pharmacol. 69: 363-368. 
45. Tunek, A., K. L. Platt, P. Bentley \& F. Oesch. 1978. Microsomal metabolism of benzene to species irreversibly binding to microsomal protein and effects of modifications of this metabolism. Mol. Pharmacol. 14: 920-929.

46. Rickert, D. E., T. S. BAKer, J. S. Bus, C. S. Barrow \& R. D. Irons. 1979. Benzene disposition in the rat after exposure by inhalation. Toxicol. Appl. Pharmacol. 49: 417-423.

47. GREENLEE, W. F., J. D. SUN \& J. S. BUS. 1981. A proposed mechanism of benzene toxicity: Formation of reactive intermediates from polyphenol metabolites. Toxicol. Appl. Pharmacol. 59: 187-195.

48. Sawahata, T. \& R. A. Neal. 1983. Biotransformation of phenol to hydroquinone and catechol by rat liver microsomes. Mol. Pharmacol. 23: 453-460.

49. JohANSSON, I. \& M. INGELMAN-SUNDBERG. 1983. Hydroxyl radical mediated cytochrome P-450-dependent metabolic activation of benzene in microsomes and reconstituted enzyme systems from rabbit liver. J. Biol. Chem. 258: 7311-7316.

50. Chance, B. \& A. C. Maehly. 1955. Assay of catalases and peroxidases. In Methods in Enzymology, Vol. II. S. P. Colowick \& N. O. Kaplan, Eds.: 764. Academic Press. New York.

51. Vanha-Perttula, T. P. J. 1960. The influence of vitamin C on eosinophil response to acute alcohol intoxication in rats. Acta Endocrinol. 35: 585-593.

52. Diluzio, N. R. 1964. Prevention of the acute ethanol-induced fatty liver by the simultaneous administration of antioxidants. Life Sci. 3: 113-118.

53. Tephly, T. R., M. Atkins, G. J. Mannering \& R. E. Parks, JR. 1965. Activation of a catalase peroxidative pathway for the oxidation of alcohols in mammalian erythrocytes. Biochem. Pharmacol. 14: 435-444.

54. PAWAN, G. S. L. 1968. Vitamins, sugars and ethanol metabolism in man. Nature 220: 374-376.

55. Busnel, R. G. \& A. G. Lehmann. 1980. Antagonistic effect of sodium ascorbate on ethanol-induced changes in swimming of mice. Behav. Brain Res. 1: 351-356.

56. Yunice, A. A. \& R. D. Lindeman. 1977. Effect of ascorbic acid and zinc sulfate on ethanol toxicity and metabolism. Proc. Soc. Exp. Biol. Med. 154: 146-150.

57. Susick, R. L., JR. \& V. G. ZANNONI. 1984. Ascorbic acid and alcohol oxidation. Biochem. Pharmacol. 24: 3963-3969.

58. Susick, R. L., JR. \& V. G. Zannoni. 1987. Ascorbic acid and elevated SGOT levels after an acute dose of ethanol in the guinea pig. Alcoholism: Clin. Exp. Res. 11 (3).

59. SUSICK, R. L., JR. \& V. G. ZANNONI. 1987. Effect of ascorbic acid on the consequences of acute alcohol consumption in man. Clin. Pharmacol. Ther. 41: 502-509.

60. Susick, R. L., JR., G. D. Abrams, C. A. Zurawski \& V. G. Zannoni. 1986. Ascorbic acid and chronic alcohol consumption in the guinea pig. Toxicol. Appl. Pharmacol. 84: 329-335.

61. Yunice, A. A., J. M. FAHMY \& S. HeNRY. 1984. Ethanol-ascorbate interrelationship in acute and chronic alcoholism in the guinea pig. Proc. Soc. Exp. Biol. Med. 177: 262-271.

62. Ohel, G., R. Kisselevitz, E. J. Margalioth \& J. G. Schenker. 1985. Ascorbatedependent lipid peroxidation in the human placenta and fetal membranes. Gynecol. Obstet. Invest. 19: 73-77.

63. SPRINCE, H. 1981. Ascorbic acid, sulfur compounds, and antiadrenergic agents as protectants against acetaldehyde toxicity: implications in alcoholism and smoking. Brit. J. Alcohol Alcoholism 16: 5-9.

64. Majchrowicz, E. \& E. P. Noble. 1979. Biochemistry and Pharmacology of Ethanol, Vol. 2. Plenum Press. New York.

65. LiEBer, C. 1982. Medical disorders of alcoholism: Pathogenesis and treatment. Major Health Problems in Internal Medicine, Vol. 22. W. B. Saunders Company. Philadephia.

66. Krasner, N., M. R. MoORe, J. Dow \& A. Goldberg. 1974. Ascorbic acid and ethanol metabolism. Lancet 21: 693-695.

67. Baraona, E. \& C. S. Lieber. 1979. Effect of ethanol lipid metabolism. J. Lipid Res. 20: 289-315.

68. Hansson, P. \& P. Nilsson-Ehle. 1983. Acute effects of ethanol and its metabolism on plasma lipids and lipoprotein lipase activity. Ann. Nutr. Metab. 27: 328-337.

69. Crouse, J. R. \& S. M. Grundy. 1984. Effects of alcohol on plasma lipoproteins and cholesterol and triglyceride metabolism in man. J. Lipid Res. 25: 486-496. 
70. Subramanian, N. 1977. On the brain ascorbic acid and its importance in metabolism of biogenic amines. Life Sci. 20: 1479-1484.

71. LoHmanN, W. 1984. Structure of ascorbic acid and its biological function. VI. Its importance for $\mathrm{Na}^{+} / \mathrm{K}^{+}$transport. Biophys. Struct. Mech. 10: 205-210.

72. Rebec, G. V., J. M. Centore, L. K. White \& K. D. Alloway. 1985. Ascorbic acid and the behavioral response to haloperidol: Implications for the action of antipsychotic drugs. Science 227: 438-440.

73. Tolbert, L. C., T. N. Thomas, L. D. Middaugh \& J. W. Zemp. 1979. Effect of ascorbic acid on neurochemical, behavioral, and physiological systems mediated by catecholamines. Life Sci. 25: 2189-2195.

\section{DISCUSSION OF THE PAPER}

B. LANE (Columbia University School of Public Health, New York, N. Y.): Did it look like there was a worsening of color vision following the pretreatment?

V. G. ZanNoni (University of Michigan Medical School, Ann Arbor, Mich.): Color vision is improved.

M. LEvine (National Institutes of Health, Bethesda, Md.): Will your effects in the guinea pig studies on alcohol be specific for ascorbic acid in terms of increasing alcohol metabolism? Did you try other reducing agents or was this effect specific for alcohol for ascorbic acid?

V. G. ZANNONI: We didn't try other reducing agents in vivo but we did measure the glutathione levels in the two groups and they were exactly the same. However, in the in vitro experiments as far as alcohol metabolism is concerned, it's relatively specific for ascorbic acid or analogues of ascorbic acid; other reducing agents have absolutely no effect.

B. N. LADu (University of Michigan Medical School, Ann Arbor, Mich.): Didn't the involvement of the catalase system as a peroxidase require the generation of peroxide, which is coming from ascorbic acid, so theoretically anything that would generate peroxide in a similar way should bring the catalases into account.

S. L. RoMNEY (Albert Einstein College of Medicine, Bronx, N.Y.): This is not meant to be facetious. On basis of your work would you recommend that liquor manufacturers supplement with some form of ascorbic acid?

V. G. ZANNONI: No actually I'd recommend that people drink less and have a few oranges a day. 